\title{
Sea-level changes and black shales associated with the late Paleocene thermal maximum: Organic-geochemical and micropaleontologic evidence from the southern Tethyan margin (Egypt-Israel)
}

\author{
Robert P. Speijer* \\ Thomas Wagner \\ Department of Geosciences, FB5, Bremen University, P.O. Box 330440, 28334 Bremen, Germany
}

\begin{abstract}
Organic geochemistry and microfossil contents of six sections spanning the late Paleocene thermal maximum are investigated. The sections are arranged along a depth transect $(\sim 50-600 \mathrm{~m})$ across an epicontinental basin covering Egypt and Israel. This study is aimed at unraveling paleoceanographic changes associated with the late Paleocene thermal maximum. In three sections ( $\sim 200-600 \mathrm{~m}$ paleodepth $)$, black shales, consisting of dark brown laminated marls with as much as $2.7 \%$ total organic carbon (TOC), mark the late Paleocene thermal maximum. The black shales of the deeper sites correlate with pink to gray fissile marls in the shallowest section. In the two remaining sections, this stratigraphic interval is missing. A relative sea-level fall $(\sim 30 \mathrm{~m})$ immediately preceded the late Paleocene thermal maximum, during which sea-level rose again by $\sim 20 \mathrm{~m}$. This rise may have been eustatically controlled, possibly through a combination of thermal expansion of the oceanic water column and melting of unknown sources of high-altitude or polar ice caps in response to global warming. During the late Paleocene thermal maximum, the upwelling of low-oxygen intermediate Tethyan water into the epicontinental basin led to enhanced biological productivity and anoxia at the seafloor. Before and after the late Paleocene thermal maximum, upwelling and biological productivity were less intense, and seafloor dysoxia was restricted to neritic parts of the basin. The presence of similar TOC-rich beds in extensive areas in southern Asia indicates that the Tethyan continental margins may have acted as significant carbon sinks during the late Paleocene thermal maximum.
\end{abstract}

\section{INTRODUCTION}

The late Paleocene thermal maximum represents an abrupt and transient period of extreme global warmth (Zachos et al., 1993). It is marked by a $\sim 90$ k.y. period ( $\sim 4.5$ precession cycles; Röhl et al., 2000) of high-latitude and deep-ocean warm- ing and is associated with major evolutionary turnovers among mammals, foraminifera, and calcareous nannofossils (Aubry et al., 1998). The onset of the late Paleocene thermal maximum coincides with the start of the most severe perturbation of the global carbon cycle during the Cenozoic (Kennett and Stott, 1991; Norris and Röhl, 1999). This perturbation, which is

*E-mail: speijer@uni-bremen.de

Speijer, R.P, and Wagner, T., 2002, Sea-level changes and black shales associated with the late Paleocene thermal maximum: Organic-geochemical and micropaleontologic evidence from the southern Tethyan margin (Egypt-Israel), in Koeberl, C., and MacLeod, K.G., eds., Catastrophic Events and Mass Extinctions: Impacts and Beyond: Boulder, Colorado, Geological Society of America Special Paper 356, p. 533-549. 
thought to have lasted $\sim 220$ k.y., is indicated by the abrupt $3 \%$ o negative carbon isotope excursion recorded in marine and terrestrial carbonates worldwide (Kennett and Stott, 1991; Koch et al., 1992; Bains et al., 1999; Röhl et al., 2000). The carbon isotope excursion is thought to have resulted from several massive methane-hydrate melting events, induced by deep ocean warming (Dickens et al., 1995; Bains et al., 1999; Katz et al., 1999; Norris and Röhl, 1999; Röhl et al., 2000). Before the late Paleocene thermal maximum, large methane-hydrate reservoirs within the sediment are thought to have been stable below $\sim 1000 \mathrm{~m}$ depth (under high pressure and relatively low temperature). Warming of intermediate and deep waters and underlying sediments with the onset of the late Paleocene thermal maximum may have disrupted the methane-hydrate stability zone, thus leading to injection of methane into the ocean and atmosphere (Dickens et al., 1995).

A direct consequence of methane release into the water column would be an increase in oxygen consumption, especially in areas where free methane is injected (Dickens, 2000a, 2001b). During the late Paleocene thermal maximum, this effect would have been most notable at intermediate depths (middle to lower bathyal) where methane-hydrate melting is thought to have occurred. Dysoxia at the seafloor and within the water column are indicated by sedimentologic and biotic data from a number of cores and localities from this depth range (Thomas, 1989, 1998; Kaiho et al., 1996; Kelly et al., 1996; Bralower et al., 1997; Katz et al., 1999). Oxygen deficiency is also regarded as one of the main causes for the largest Cenozoic extinction (40\%) of deep-sea benthic foraminifera (Thomas, 1998, and references therein). This extinction, known as the benthic extinction event, has also been demonstrated, albeit in a milder form, in neritic successions bordering the Tethys and Atlantic (Speijer et al., 1996a, 1996b; Cramer et al., 1999).

Epicontinental basins bordering the Tethys appear to have been particularly prone to severe oxygen deficiency during the late Paleocene thermal maximum. A total organic carbon (TOC) rich sapropelite unit as thick as $1 \mathrm{~m}$ has been recorded in numerous localities over a vast area between the Crimea and Uzbekistan (northern Tethyan margin) by Gavrilov et al. (1997). Gavrilov et al. (1997) noted TOC-rich (to 17\%), laminated beds with enrichments of a suite of elements typical of deposition under suboxic to anoxic conditions. Similarly, Speijer et al. (1997) found dark sapropelic beds with micropaleontologic indications for anoxia in association with the benthic extinction event in localities in Turkmenistan (northern Tethys) and Egypt (southern Tethys). We refer to these deposits as black shales (Tyson, 1987). For their corresponding oxygen-depleted environments we adopted the nomenclature of Tyson and Pearson (1991). Chemostratigraphic and biostratigraphic studies indicate that the black shales on both Tethyan margins correlate with the onset and early part of the carbon isotope excursion and the late Paleocene thermal maximum (Speijer et al., 2000).

In this chapter we provide a paleoenvironmental synthesis of an area on the southern Tethyan margin (Egypt-Israel) in an $\sim 2$ m.y. interval comprising the late Paleocene thermal maximum. It builds upon the stratigraphic framework in Speijer et al. (2000), which was constructed through biostratigraphic and chemostratigraphic interpretation of five of the six sections on a north-south paleobathymetric transect presented here (Fig. 1). We draw the paleoenvironmental information from microbiotic (mostly benthic foraminifera) interpretations published in earlier reports (e.g., Speijer et al., 1996b, 1997), and complement these by new microbiotic, sedimentologic, and organic-petrographic and/or geochemical observations and data. Late Paleocene to early Eocene paleoenvironments of four sections (Gebel Aweina, Gebel Duwi, Ben Gurion, and Wadi Nukhl) have been intensively discussed, also by others (Table 1). For addi-

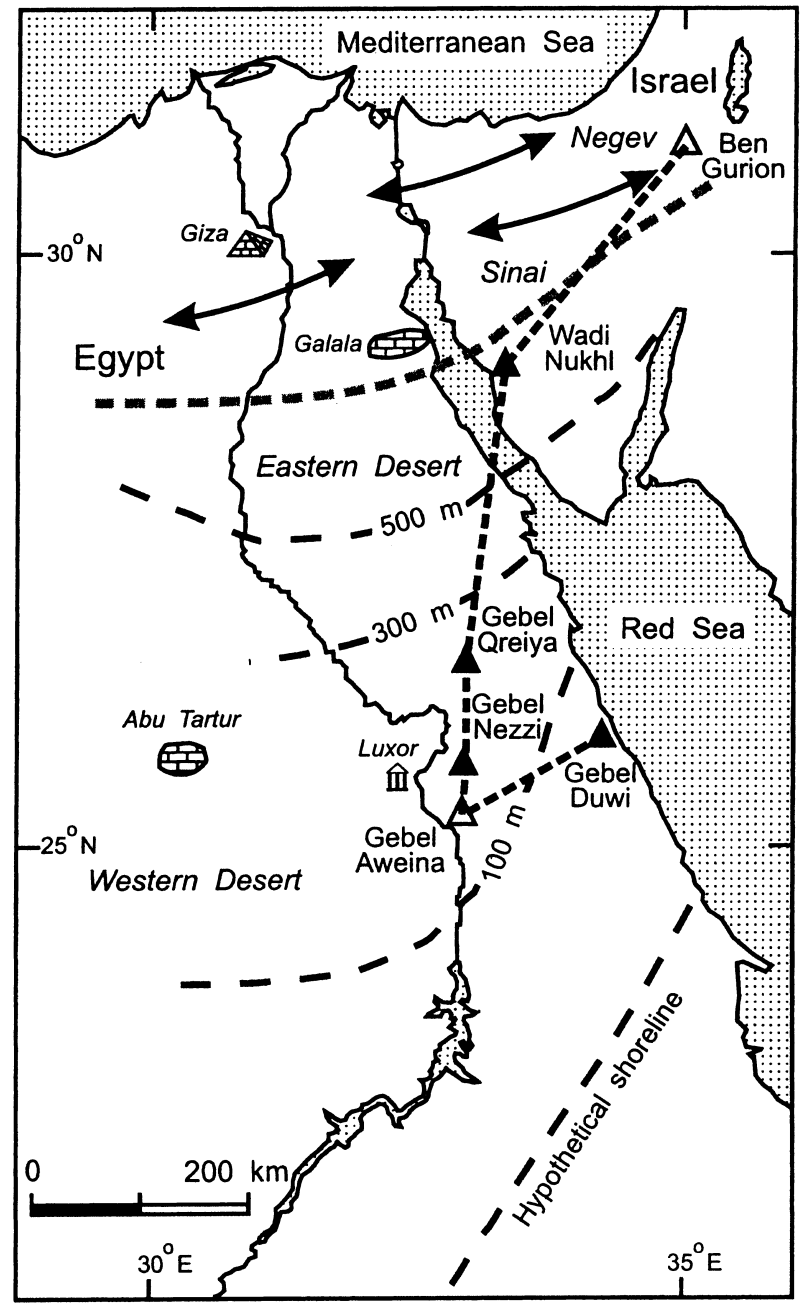

Figure 1. Location map with reconstructed late Paleocene paleogeography and paleobathymetry (no correction for opening of Red Sea rift). Filled triangles indicate sections containing subzone P5b (early part of carbon isotope excursion-late Paleocene thermal maximum); open triangles represent sections that do not contain subzone P5b. Thick dashed line separates tectonically stable shelf in south from tectonically active unstable shelf (Syrian arc) in north. Arrows indicate general orientation of double-plunging anticlines (submarine swells) of unstable shelf. Modified from Speijer et al. (2000). 
TABLE 1. PREVIOUS STUDIES DEFINING PALEOENVIRONMENTAL PARAMETERS

\begin{tabular}{|c|c|c|c|c|c|}
\hline Parameter & Ben Gurion* & Wadi Nukhl† & Gebel Qreiya & Gebel Aweina & Gebel Duwi \\
\hline Depth and/or sea level & $1,2,4,5,9$ & $2,10,14$ & 14 & $2,6,7$ & $2,6,8,9,14$ \\
\hline Oceanic circulation & $1,2,4,5,9,11,13$ & $2,10,14$ & 14 & $2,3,6,11$ & $2,6,8,9,11,14$ \\
\hline Surface productivity & $1,5,9,11,13$ & $2,10,14$ & 14 & $2,3,6,11$ & $2,6,8,9,11,14$ \\
\hline Bottom oxygenation & $1,2,4,9,11$ & 2,10 & N.D. & $2,6,11$ & $2,6,8,9,11$ \\
\hline Temperature & 11,13 & N.D. & N.D. & 6,11 & 6,11 \\
\hline Salinity & 11 & N.D. & N.D. & 6,11 & 6,11 \\
\hline Climate & $5,9,13,11$ & 2,14 & 14 & $2,6,11$ & $2,6,8,9,11,14$ \\
\hline
\end{tabular}

Note: 1 = Benjamini, 1992; 2 = Speijer, 1994; 3 = Charisi and Schmitz, 1995; 4 = Speijer, 1995; 5 = Lu et al., 1996; 6 = Schmitz et al., 1996; 7 = Speijer et al., 1996a; 8 = Speijer et al., 1996b; 9 = Schmitz et al., 1997; 10 = Speijer et al., 1997; $11=$ Charisi and Schmitz, $1998 ; 12=$ Speijer and Schmitz, 1998; 13 = Bolle et al., 2000a; 14 = Bolle et al., 2000b.

${ }^{*}$ Also known as Nahal Avdat in refs. 2 and 4

tIn ref. 14 the nearby Gebel Matulla.

N.D.-Not discussed previously.

tional stratigraphic studies on the sections discussed here, we refer to the references cited, and the literature cited therein, in Table 1. In addition, two less well-studied sections, Gebel Nezzi and Gebel Qreiya, provide new key data to the synthesis presented here. We focus on the relationship between the deposition of the black shales and the relative sea-level record of the area.

\section{GEOLOGIC SETTING}

The studied sections are in the eastern part of an extensive epicontinental basin that covered most of Egypt, Israel, and Jordan at the end of the Paleocene. The Egyptian sections are located on the so-called stable shelf, which underwent relatively little structural deformation during the Late Cretaceous and early Paleogene (Said, 1962). The Ben Gurion section is on the unstable shelf, also known as the Syrian arc, a fold belt that has been active since the Late Cretaceous (Shahar, 1994). Disregarding the structural highs of the Syrian arc, the basin generally deepened in a northwest direction. Microbiota indicate that the shallowest deposition (middle neritic, $\sim 50-100 \mathrm{~m}$ ) was at Gebel Duwi, and the deepest (upper bathyal, 500-600 m) was at Wadi Nukhl and Ben Gurion. Deposition at the Gebels Aweina, Nezzi, and Qreiya occurred at $\sim 200 \mathrm{~m}$ paleodepth (Fig. 1). We use the terms neritic and bathyal as representing paleodepths less than and in excess of $200 \mathrm{~m}$, respectively (Van Morkhoven et al., 1986). However, the true continental slope was situated north of the epicontinental basin studied (Mart, 1991).

\section{STRATIGRAPHY}

In Egypt, upper Paleocene to lower Eocene marls and shales are usually classified as the Esna Formation. The Esna Formation is intercalated between two more calcareous units, the upper Paleocene Tarawan Formation and the lower Eocene Thebes Formation (Said, 1990). In southern Israel, other lithostratigraphic units (Taqiye Formation, Hafir Member and Mor Formation, respectively) are employed, but the stratigraphic succession is very similar there (Benjamini, 1992). The Esna Formation and its lateral equivalents consist mostly of monotonous and fissile gray to brown-green marls and shales, containing abundant and mostly well-preserved calcareous microbiota. The fissile character relates to the generally high smectite contents of the clay fraction (Strouhal, 1993; Bolle et al., 2000a, 2000b). In the interval of major biotic changes associated with the late Paleocene thermal maximum and carbon isotope excursion, however, beds as thick as $1 \mathrm{~m}$ of different lithologies (black shales and foraminifera-rich calcarenitic marls) are present. These black shales should not be confused with occasional dark gray to black beds present in many Paleocene marl successions in the region (see following). The stratigraphic framework for all sections but Nezzi is based on planktic and benthic foraminifera and carbon isotopes (Speijer et al., 2000). For Nezzi, only foraminiferal data are available. Further calcareous nannofossil data pertaining explicitly to the late Paleocene thermal maximum in these sections were presented in Speijer (1995), Schmitz et al. (1996), Bolle et al. (2000b), and Monechi et al. (2000). The stratigraphic interval documented here is bracketed by the base of the Esna Formation (uppermost part of zone P4) below, and by the P5-P6 zonal boundary above (Fig. 2). We adopted biostratigraphic terminology from Berggren et al. (1995). Subdivision of zone P5 (subzones P5a-P5c), however, is after Speijer et al. (2000). Subzone P5b (Morozovella allisonensis total range subzone) constitutes the lower part of the stratigraphic interval spanning the carbon isotope excursion and the late Paleocene thermal maximum (black shales). This subzone is present in four of our sections. In the Gebel Aweina and Ben Gurion sections, omission surfaces, characterized by a sharp but burrowed contact between the pre-late Paleocene thermal maximum marls and the calcarenitic marls, mark discontinuities at this level.

\section{MATERIAL AND METHODS}

Samples were collected from decimeter-deep trenches or holes along the outcrop sections. Some influence of weathering cannot be ruled out (van Os et al., 1996). For Duwi, Aweina, 
Figure 2. Stratigraphic correlation chart of lower part of Esna and Taqiye Formations along paleodepth transect. Whole-rock $\delta^{13} \mathrm{C}$ excursions (CIE, carbon isotope excursion; w-r, whole rock) coincide with benthic foraminiferal extinction event. Initiation and termination of CIE is uncertain at Qreiya. Large isotopic shift below carbon isotope excursion in Duwi results from diagenesis (Speijer et al., 2000). Modified from Speijer et al. (2000). LPTM is late Paleocene thermal maximum.

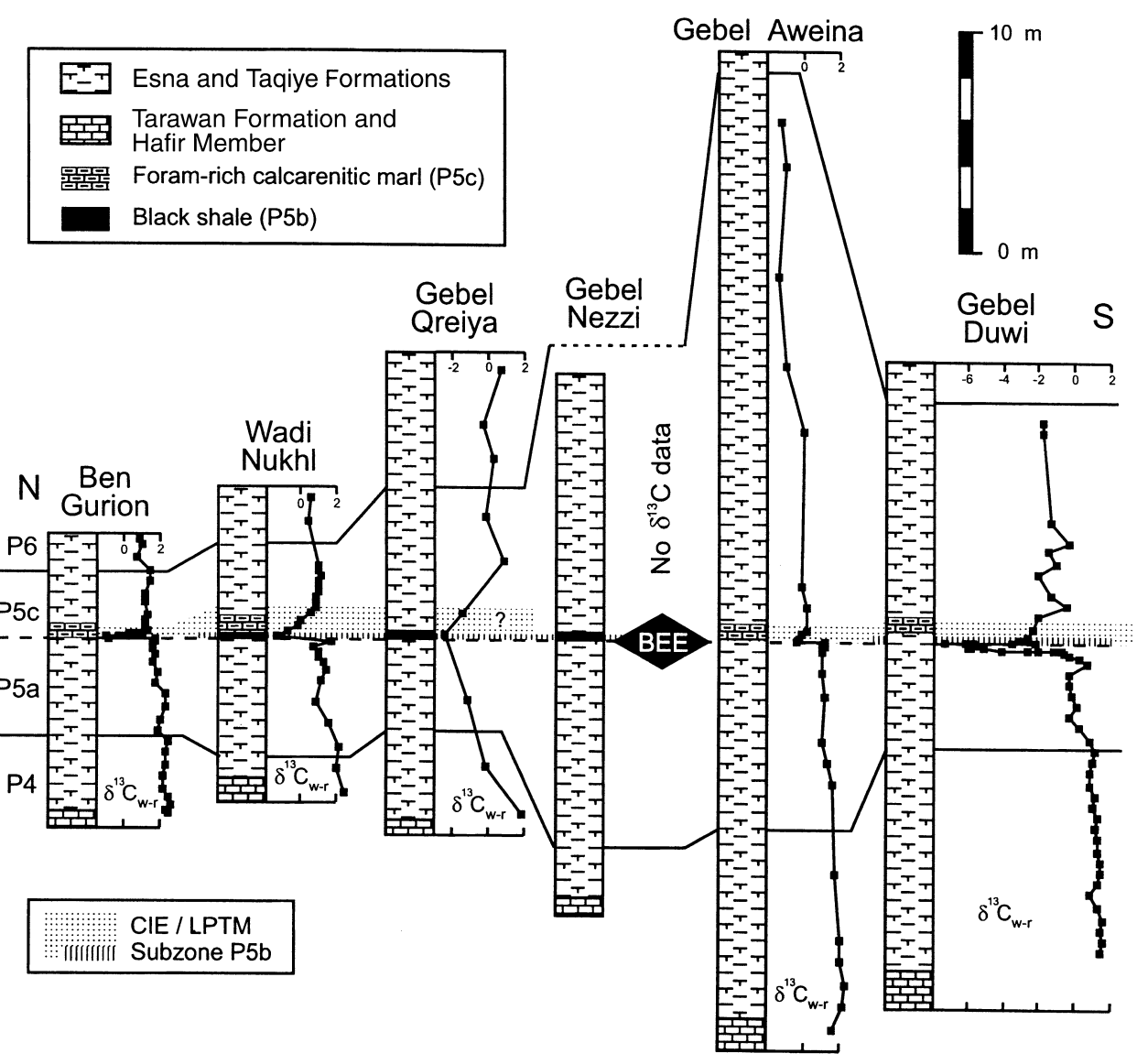

and Ben Gurion, high-resolution (centimeter scale) sample sets across the late Paleocene thermal maximum were available. The Nukhl, Qreiya, and Nezzi sections were logged and sampled with little (Nukhl) or no prior knowledge on the late Paleocene thermal maximum (Nezzi and Qreiya, sampled by F. Hendriks and P. Luger, personal commun., 1985). Accordingly, only medium- to low-resolution (25-200 cm sample spacing) sets were available, each yielding one sample in the black shales. Herein only the lower half of the sapropelic bed in Nukhl (Speijer et al., 1997, 2000) is considered as black shale. The upper half (brown bioturbated marl) and the overlying calcarenitic marls are discussed together. All samples were processed according to standard micropaleontologic procedures. Stratigraphic and compositional data of the foraminiferal assemblages were determined qualitatively and quantitatively (e.g., Speijer et al., 1996b). In this chapter we summarize micropaleontologic data from Speijer et al. (1996a, 1996b, 1997) and Speijer and Schmitz (1998), and incorporate new observations on samples from Duwi, Nezzi, Aweina, and Qreiya.

Geochemical analyses were performed on the three sections (Nukhl, Nezzi, Qreiya) containing the peculiar black shale bed within subzone P5b, immediately above the benthic extinction event. Additional $\mathrm{CaCO}_{3}$ results of Aweina, Duwi, and Ben Gurion can be found in Schmitz et al. (1996, 1997). Values of organic and inorganic carbon were measured on homogenized samples using a Leco CS-300 elemental analyzer at Bremen University (precision of measurement $\pm 3 \%$ ). Before determination of organic carbon, calcium carbonate was removed by repetitive addition of $0.25 \mathrm{~N} \mathrm{HCl}$. The carbonate content was calculated from the difference between total and organic carbon and expressed as calcite $\left(\mathrm{CaCO}_{3}=\left[\mathrm{C}_{\text {total }}-\mathrm{C}_{\text {organic }}\right]\right.$ $\times$ 8.33). Rock-Eval pyrolysis was run on whole-rock samples at the Alfred Wegener Institute in Bremerhaven according to the procedures described by Espitalié et al. (1985). Hydrogen indices (HI) were calculated using TOC values obtained from Leco analysis. Organic petrologic analyses were performed on resin-embedded bulk sediment samples using a Zeiss Axiophot, equipped with incident white and reflected ultraviolet light.

\section{RESULTS}

\section{Background sedimentation}

The $\mathrm{CaCO}_{3}$ contents of the marls of the Esna Formation (Fig. 3) show an overall decline from the top of the Tarawan Formation $(\sim 70 \%)$ upward to just below the late Paleocene thermal maximum $(10 \%-40 \%)$. In the calcarenitic foraminiferarich marl beds above the benthic extinction event in Nukhl (as 


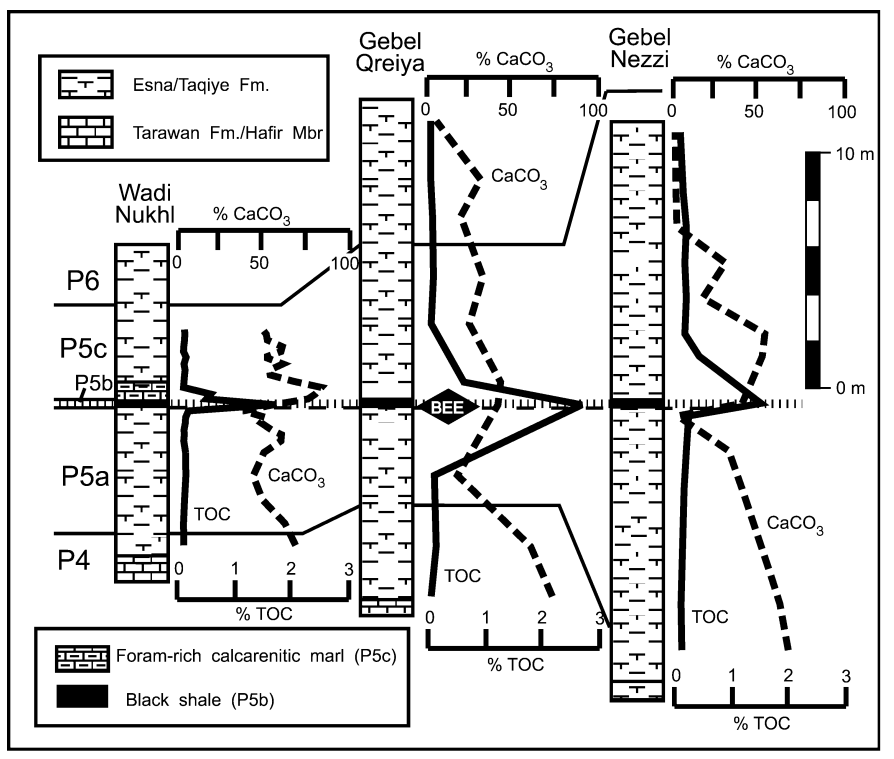

Figure 3. $\mathrm{CaCO}_{3}$ and total organic carbon (TOC) profiles of lower part of Esna Formation in three sections containing late Paleocene thermal maximum black shale. Black shales are characterized by peak values in TOC content $(1.5 \%-2.7 \%)$ and average $\mathrm{CaCO}_{3}$ contents $(40 \%-$ $50 \%)$.

in Aweina, Ben Gurion, and Duwi; see Schmitz et al., 1996, 1997), this decline is followed by a temporary $\mathrm{CaCO}_{3}$ peak $(\sim 80 \%)$. In Nezzi and Qreiya this peak is less pronounced $\left(\sim 50 \% \mathrm{CaCO}_{3}\right)$. The temporary peaks are followed by a further general decline upward in all sections except Ben Gurion (see also Schmitz et al., 1996, 1997). Intervals marked by severe postdepositional dissolution distort this general pattern, particularly in the neritic sections. Beyond the late Paleocene thermal maximum, the TOC content of the Esna Formation is invariably low, ranging between $0 \%$ and $0.2 \%$.

Planktic foraminifera assemblages from all sections are generally rich and diverse, mainly consisting of species of the genera Morozovella, Acarinina, Globanomalina, and Subbotina. Planktic/Benthic (P/B) ratios of well-preserved assemblages range from $70 \%$ to $95 \%$ planktics. Taphonomic processes leading to dissolution and fragmentation, however, have occasionally reduced this value to $5 \%-50 \%$ planktics. Consequently, there is no distinct decrease in $\mathrm{P} / \mathrm{B}$ ratios from the deeper to shallower localities.

The following benthic foraminiferal data are largely from earlier papers (Speijer, 1994, 1995; Speijer et al., 1996a, 1996b, 1997; Speijer and Schmitz, 1998). Beyond the late Paleocene thermal maximum, seven main benthic assemblages can be bathymetrically ordered (Fig. 4). The nominate taxa of the main assemblages are the most common and/or characteristic ones. Before the benthic extinction event, the Frondicularia phosphatica assemblage is restricted to the middle neritic Duwi section, the Angulogavelinella avnimelechi assemblage characterizes the outer neritic localities, and the Gavelinella bec- cariiformis assemblage marks bathyal deposits. In Duwi, the Anomalinoides aegyptiacus assemblage gradually replaced the F. phosphatica assemblage just prior to the benthic extinction event. Well after the benthic extinction event, the Valvulineria scrobiculata assemblage succeeds the A. aegyptiacus assemblage there. Overall, the Bulimina callahani assemblage replaced the outer neritic A. avnimelechi assemblage and the Nuttallides truempyi assemblage succeeded the G. beccariiformis assemblage of the deepest localities. The deepest assemblages are composed of a mixture of deep-sea and neritic taxa, whereas the outer neritic assemblages contain $<10 \%$ deep-sea taxa.

Other biotic components of the micropaleontologic residues are ostracodes (common in Duwi, rare elsewhere), fish scales and teeth (rare to common), radiolarians (abundant at the base of the Esna Formation in Nukhl and Ben Gurion), and rare molds of juvenile gastropods. Not a single sample yielded dinocysts, spores, or pollen (H. Brinkhuis, 1994, 1999, personal communs.).

\section{Sedimentation during late Paleocene thermal maximum and carbon isotope excursion}

Geochemistry of black shales. The late Paleocene thermal maximum black shale beds in Nukhl, Qreiya, and Nezzi are 25-50 $\mathrm{cm}$ thick (Table 2). They consist of dark brown marls ( $\sim 40 \%-$ $50 \% \mathrm{CaCO}_{3}$; Fig. 3; Table 3) that contain abundant phosphatic peloids (Fig. 5, A and B) and 1.5\% (Nezzi) to $2.7 \%$ TOC (Qreiya). The overlying beds show a modest $(0.5 \%)$ TOC enrichment. Fluorescence petrography of these beds reveals a fine wavy-laminated sedimentary texture and abundant threads of weakly fluorescent marine amorphous organic matter. This pattern is well known from many other TOC-rich shales deposited under conditions of oxygen depletion (e.g., Wignall, 1994). Larger, structured organic particles (macerals) are rare and mostly reveal a weak, brownish fluorescence. Stronger fluorescing liptinites are restricted to algae bodies, showing characteristic internal structures (Fig. 5C). Terrestrial organic matter is rare and very small $(\ll 5 \mu \mathrm{m})$.

Despite qualifying as typical black shales (Tyson, 1987), these beds differ from other marine black shales with regard to their thermal signature and hydrocarbon charging (e.g., Kuhnt et al., 1990; Mostafa, 1993; Mello et al., 1995; Alsharhan and Salah, 1997; Wagner and Pletsch, 1999). Rock-Eval data from the late Paleocene thermal maximum black shales and similar middle Paleocene TOC-rich units in Egypt (Table 3) reveal pyrolytic signatures indicative of preservation of extremely hydrogen-depleted organic matter ( $\mathrm{S} 2$ yields $<0.35 \mathrm{mg} \mathrm{HC} / \mathrm{g}$ TOC corresponding to $\mathrm{HI}<30 \mathrm{mg} \mathrm{HC} / \mathrm{g}$ TOC). These low hydrogen indices favor the presence of severely oxidized type IV kerogen, which is commonly associated with TOC-poor, oxic depositional environments (Jones, 1987) rather than with dysoxic and/or anoxic settings, where hydrocarbon source rocks accumulate.

Optical properties of the shales, however, challenge the 


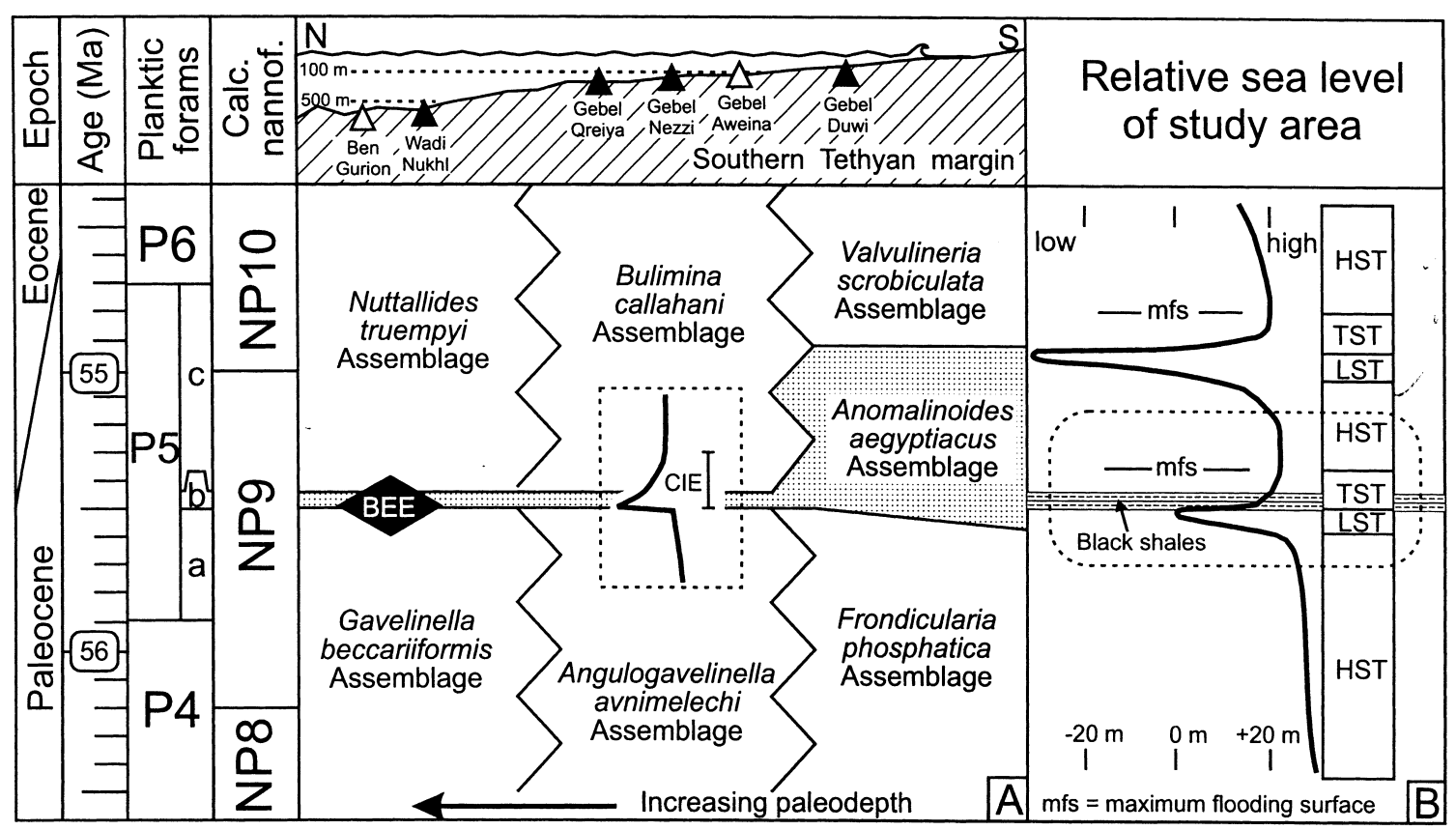

Figure 4. A: Schematic spatial and temporal distribution of main benthic foraminifera assemblages. Inset shows schematic profile and duration of carbon isotope excursion (CIE). B: Relative sea-level curve of area and sequence-stratigraphic interpretation. All data are plotted against biostratigraphic and chronostratigraphic schemes of Berggren et al. (1995). Note that estimated age of initiation of late Paleocene thermal maximum in this scheme is slightly older than astronomically calibrated age (ca. $54.95 \mathrm{Ma}$ ) of Norris and Röhl (1999). Subdivision of zone P5 is after Speijer et al. (2000). HST, TST, and LST are highstand, transgressive, and lowstand systems tracts, respectively.

TABLE 2. DIMENSIONS OF LATE PALEOCENE THERMAL MAXIMUM/CARBON ISOTOPE EXCURSION RELATED PARAMETERS

\begin{tabular}{|c|c|c|c|c|c|c|}
\hline Unit & $\begin{array}{l}\text { Ben Gurion } \\
\text { (in cm) }\end{array}$ & $\begin{array}{l}\text { Wadi Nukhl } \\
\text { (in cm) }\end{array}$ & $\begin{array}{l}\text { Gebel Qreiya } \\
\text { (in } \mathrm{cm} \text { ) }\end{array}$ & $\begin{array}{l}\text { Gebel Nezzi } \\
\quad \text { (in } \mathrm{cm} \text { ) }\end{array}$ & $\begin{array}{l}\text { Gebel Aweina } \\
\text { (in } \mathrm{cm} \text { ) }\end{array}$ & $\begin{array}{l}\text { Gebel Duwi } \\
\text { (in } \mathrm{cm} \text { ) }\end{array}$ \\
\hline $\begin{array}{l}\text { Calcarenitic marl } \\
\text { Black shale (Zone P5b) } \\
\text { CIE }\end{array}$ & $\begin{array}{l}20 \\
\text { N.A. } \\
30\end{array}$ & $\begin{array}{r}75 \\
\sim 25 \\
110\end{array}$ & $\begin{array}{l}\text { N.A. } \\
\sim 40 \\
\text { N.D. }\end{array}$ & $\begin{array}{l}\text { N.A. } \\
\sim 50 \\
\text { N.D. }\end{array}$ & $\begin{array}{l}40 \\
\text { N.A. } \\
30\end{array}$ & $\begin{array}{l}\sim 60 \\
\sim 25^{\star} \\
\sim 80\end{array}$ \\
\hline
\end{tabular}

${ }^{*}$ Fissile marl correlating with black shales

Note: N.D. = No or insufficient data

N.A. $=$ Not applicable

idea of an oxic environment, and suggest alternative explanations. In this respect, maximum temperature values $\left(T_{\max }\right)$ obtained by Rock-Eval analysis need to be considered. $T_{\max }$ depicts the temperature of maximum hydrocarbon generation from the kerogen fraction (S2), and is a direct measure of the thermal maturity of the organic matter. By definition, organic matter is considered thermally immature if $T_{\max }$ is below $435^{\circ} \mathrm{C}$ $(<0.5 \%-0.6 \% \mathrm{Rm}$ vitrinite reflectance), mature between 435 and $460^{\circ} \mathrm{C}$ (to $1.3 \% \mathrm{Rm}$ ), and overmature when exceeding $460^{\circ} \mathrm{C}$ (Tissot and Welte, 1984). $T_{\max }$ data obtained from the late Paleocene thermal maximum black shales and middle Paleocene intervals show, with the exception of the black shale from Nezzi, thermally mature to overmature organic matter. Being aware of the analytical problems of $T_{\max }$ detection in the presence of very low hydrocarbon yields (Wagner and Dupont,
1999), we consider the consistency of $T_{\max }$ signatures to be at least indicative for the organic matter maturity stage.

Micropaleontology of black shales. Planktic foraminifera, particularly Acarinina spp., are the most abundant component of the black shales. The marker species of subzone P5b, Morozovella allisonensis, is rare (Nukhl) to common (Qreiya), whereas other Morozovella are very rare. Benthic foraminifera are also rare, leading to unusually high $\mathrm{P} / \mathrm{B}$ ratios (99\% planktics) in all black shale samples. Three benthic species (Anomalinoides aegyptiacus, Stainforthia farafraensis, and Valvulineria sp.) make up $\sim 95 \%$ of the benthic assemblages (Fig. 6). These three taxa are otherwise very rare in outer neritic and deeper deposits in the region, but the former two are common to abundant in middle neritic deposits of Gebel Duwi. Preservation of the foraminifera varies from poor (Nukhl; recrystal- 
TABLE 3. ELEMENTAL AND PYROLYTIC DATA FROM STUDIED SEDIMENTS

\begin{tabular}{|c|c|c|c|c|c|c|c|}
\hline Profile & Sample & $\begin{array}{l}\text { Level } \\
(\mathrm{m})\end{array}$ & $\begin{array}{c}\text { TOC } \\
(\%)\end{array}$ & $\begin{array}{c}\mathrm{CaCO}_{3} \\
(\%)\end{array}$ & $\begin{array}{l}\text { Stot } \\
(\%)\end{array}$ & $\begin{array}{l}T_{\max } \\
\left({ }^{\circ} \mathrm{C}\right)\end{array}$ & $\begin{array}{c}\text { Hydrogen Index } \\
\text { (mgHC/gTOC) }\end{array}$ \\
\hline G. Qreiya, 271185 & $\begin{array}{l}20 \\
21 \\
22 \\
23 \\
24 \\
25 \\
26 \\
28 \\
29 \\
30\end{array}$ & $\begin{array}{r}20.4 \\
17.9 \\
16.4 \\
13.8 \\
11.8 \\
9.4 \\
8.4 \\
5.4 \\
2.4 \\
0.3\end{array}$ & $\begin{array}{l}0.10 \\
0.11 \\
0.13 \\
0.15 \\
0.11 \\
0.65 \\
2.74 \\
0.16 \\
0.20 \\
0.11\end{array}$ & $\begin{array}{l}10.69 \\
36.37 \\
24.92 \\
37.80 \\
29.65 \\
47.66 \\
46.08 \\
22.94 \\
64.85 \\
77.59\end{array}$ & $\begin{array}{l}0.06 \\
0.16 \\
0.12 \\
0.09 \\
0.11 \\
0.09 \\
0.22 \\
0.08 \\
0.14 \\
0.08\end{array}$ & $\begin{array}{l}\text { N.D. } \\
\text { N.D. } \\
\text { N.D. } \\
\text { N.D. } \\
\text { N.D. } \\
\text { N.D. } \\
502 \\
\text { N.D. } \\
\text { N.D. } \\
\text { N.D. }\end{array}$ & $\begin{array}{l}\text { N.D. } \\
\text { N.D. } \\
\text { N.D. } \\
\text { N.D. } \\
\text { N.D. } \\
\text { N.D. } \\
11 \\
\text { N.D. } \\
\text { N.D. } \\
\text { N.D. }\end{array}$ \\
\hline G. Nezzi, 41285 & $\begin{array}{r}19 \\
18 \\
17 \\
16 \\
15 \\
14 \\
13 \\
12 \\
11 \\
10 \\
9 \\
8 \\
7 \\
6\end{array}$ & $\begin{array}{l}22.5 \\
20 \\
18.5 \\
17 \\
15.5 \\
14 \\
13 \\
11 \\
10.5 \\
9 \\
8 \\
5.5 \\
2.5 \\
0.5\end{array}$ & $\begin{array}{l}0.08 \\
0.12 \\
0.17 \\
0.15 \\
0.17 \\
0.13 \\
0.38 \\
1.46 \\
0.19 \\
0.16 \\
0.14 \\
0.11 \\
0.08 \\
0.10\end{array}$ & $\begin{array}{r}0.03 \\
0.10 \\
1.10 \\
28.71 \\
15.07 \\
50.85 \\
48.93 \\
36.38 \\
0.00 \\
29.94 \\
34.25 \\
45.06 \\
58.34 \\
63.62\end{array}$ & $\begin{array}{l}0.45 \\
0.03 \\
0.05 \\
0.1 \\
0.05 \\
0.45 \\
0.09 \\
0.19 \\
0.07 \\
0.26 \\
0.09 \\
0.09 \\
0.06 \\
0.14\end{array}$ & $\begin{array}{l}\text { N.D. } \\
\text { N.D. } \\
\text { N.D. } \\
\text { N.D. } \\
\text { N.D. } \\
\text { N.D. } \\
\text { N.D. } \\
362 \\
\text { N.D. } \\
\text { N.D. } \\
\text { N.D. } \\
\text { N.D. } \\
\text { N.D. } \\
\text { N.D. }\end{array}$ & $\begin{array}{l}\text { N.D. } \\
\text { N.D. } \\
\text { N.D. } \\
\text { N.D. } \\
\text { N.D. } \\
\text { N.D. } \\
\text { N.D. } \\
1 \\
\text { N.D. } \\
\text { N.D. } \\
\text { N.D. } \\
\text { N.D. } \\
\text { N.D. } \\
\text { N.D. }\end{array}$ \\
\hline Wadi Nukhl & $\begin{array}{l}1385 \\
1384 \\
1383 \\
1382 \\
1381 \\
1380 \\
1379 \\
1378 \\
1377 \\
1376 \\
1375 \\
1374 \\
1373 \\
1372 \\
1371 \\
1370 \\
1369 \\
1368 \\
1367 \\
1366 \\
1364 \\
1363 \\
1362 \\
1361 \\
1360\end{array}$ & $\begin{array}{l}9.55 \\
9.3 \\
9.05 \\
8.8 \\
8.55 \\
8.3 \\
8.05 \\
7.8 \\
7.55 \\
7.3 \\
7.05 \\
6.8 \\
6.55 \\
6.3 \\
6.05 \\
5.8 \\
5.55 \\
5.3 \\
5.05 \\
4.8 \\
4.3 \\
3.3 \\
2.3 \\
1.3 \\
0.3\end{array}$ & $\begin{array}{l}0.08 \\
0.08 \\
0.08 \\
0.06 \\
0.07 \\
0.10 \\
0.07 \\
0.08 \\
0.08 \\
0.07 \\
0.06 \\
0.55 \\
0.41 \\
1.55 \\
0.15 \\
0.09 \\
0.09 \\
0.07 \\
0.07 \\
0.07 \\
0.10 \\
0.10 \\
0.08 \\
0.06 \\
0.06\end{array}$ & $\begin{array}{l}48.05 \\
50.88 \\
51.74 \\
60.39 \\
59.22 \\
49.36 \\
61.31 \\
52.63 \\
53.11 \\
66.48 \\
82.58 \\
79.61 \\
73.98 \\
53.29 \\
36.49 \\
51.61 \\
47.21 \\
53.00 \\
59.48 \\
59.14 \\
49.71 \\
43.48 \\
48.71 \\
61.19 \\
67.84\end{array}$ & $\begin{array}{l}0.14 \\
0.15 \\
0.14 \\
0.08 \\
0.08 \\
0.04 \\
0.14 \\
0.13 \\
0.15 \\
0.16 \\
0.05 \\
0.05 \\
1.57 \\
0.22 \\
0.41 \\
0.18 \\
0.13 \\
0.14 \\
0.13 \\
0.17 \\
0.14 \\
0.16 \\
0.12 \\
0.15 \\
0.18\end{array}$ & $\begin{array}{l}\text { N.D. } \\
\text { N.D. } \\
\text { N.D. } \\
\text { N.D. } \\
\text { N.D. } \\
\text { N.D. } \\
\text { N.D. } \\
\text { N.D. } \\
\text { N.D. } \\
\text { N.D. } \\
\text { N.D. } \\
\text { N.D. } \\
\text { N.D. } \\
506 \\
\text { N.D. } \\
\text { N.D. } \\
\text { N.D. } \\
\text { N.D. } \\
\text { N.D. } \\
\text { N.D. } \\
\text { N.D. } \\
\text { N.D. } \\
\text { N.D. } \\
\text { N.D. } \\
\text { N.D. }\end{array}$ & $\begin{array}{l}\text { N.D. } \\
\text { N.D. } \\
\text { N.D. } \\
\text { N.D. } \\
\text { N.D. } \\
\text { N.D. } \\
\text { N.D. } \\
\text { N.D. } \\
\text { N.D. } \\
\text { N.D. } \\
\text { N.D. } \\
\text { N.D. } \\
\text { N.D. } \\
7 \\
\text { N.D. } \\
\text { N.D. } \\
\text { N.D. } \\
\text { N.D. } \\
\text { N.D. } \\
\text { N.D. } \\
\text { N.D. } \\
\text { N.D. } \\
\text { N.D. } \\
\text { N.D. } \\
\text { N.D. }\end{array}$ \\
\hline $\begin{array}{l}\text { G. Nezzi, } 51285 \\
\text { (Mid Paleocene) }\end{array}$ & $\begin{array}{l}21 \\
19 \\
17\end{array}$ & $\begin{array}{l}\text { N.A. } \\
\text { N.A. } \\
\text { N.A. }\end{array}$ & $\begin{array}{l}0.13 \\
0.91 \\
0.15\end{array}$ & $\begin{array}{l}45.75 \\
51.85 \\
18.06\end{array}$ & $\begin{array}{l}0.11 \\
0.43 \\
0.04\end{array}$ & $\begin{array}{l}\text { N.D. } \\
501 \\
446\end{array}$ & $\begin{array}{c}\text { N.D. } \\
10 \\
123\end{array}$ \\
\hline $\begin{array}{l}\text { G. Qreiya, } 271185 \\
\text { (Mid Paleocene) }\end{array}$ & $\begin{array}{l}40 \\
41 \\
42\end{array}$ & $\begin{array}{l}\text { N.A. } \\
\text { N.A. } \\
\text { N.A. }\end{array}$ & $\begin{array}{l}1.03 \\
2.38 \\
0.32\end{array}$ & $\begin{array}{r}7.13 \\
46.29 \\
6.07\end{array}$ & $\begin{array}{l}0.12 \\
3.84 \\
0.14\end{array}$ & $\begin{array}{l}501 \\
467 \\
509\end{array}$ & $\begin{array}{l}17 \\
15 \\
31\end{array}$ \\
\hline
\end{tabular}

Note: Mid-Paleocene data are included for comparison of $T_{\max }$ values. TOC $=$ total organic carbon; Stot $=$ total sulfur; $T_{\max }=$ temperature of maximum hydrocarbon generation rate obtained from the kerogen fraction (52 window) by Rock-Eval Pyrolysis; N.D. = No data; N.A. = Not applicable. 
Figure 5. A: Thin section of late Paleocene thermal maximum black shale at Gebel Nezzi, showing numerous pale phosphatic peloids (coprolites) in finely laminated dark brown matrix. Scale bar is $1 \mathrm{~cm}$. B: Polarized light microscope image of $\mathrm{A}$, showing wavy lamination around phosphatic peloids and other grains (e.g., foraminifera), induced by compaction (Wignall, 1994). Scale bar is $400 \mu \mathrm{m}$. C: Fluorescence petrography of A, showing rare algal body with internal structures. Black shales at Nukhl and Qreiya are sedimentologically and petrographically very similar. Scale bar is $100 \mu \mathrm{m}$.
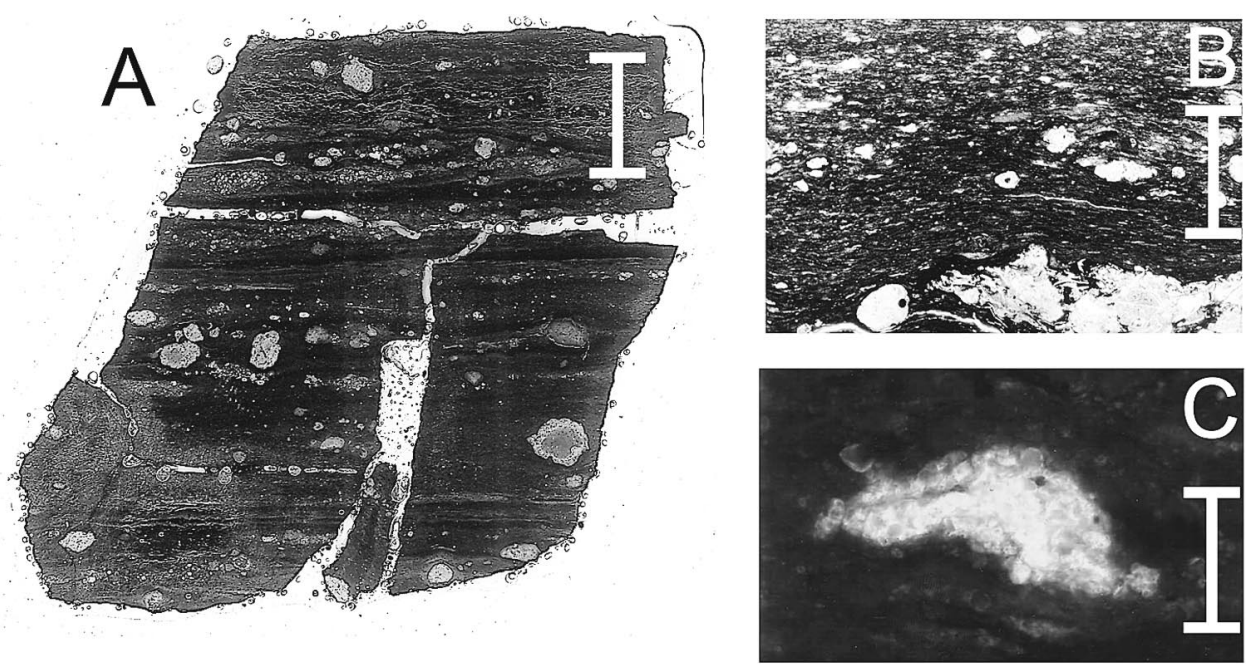

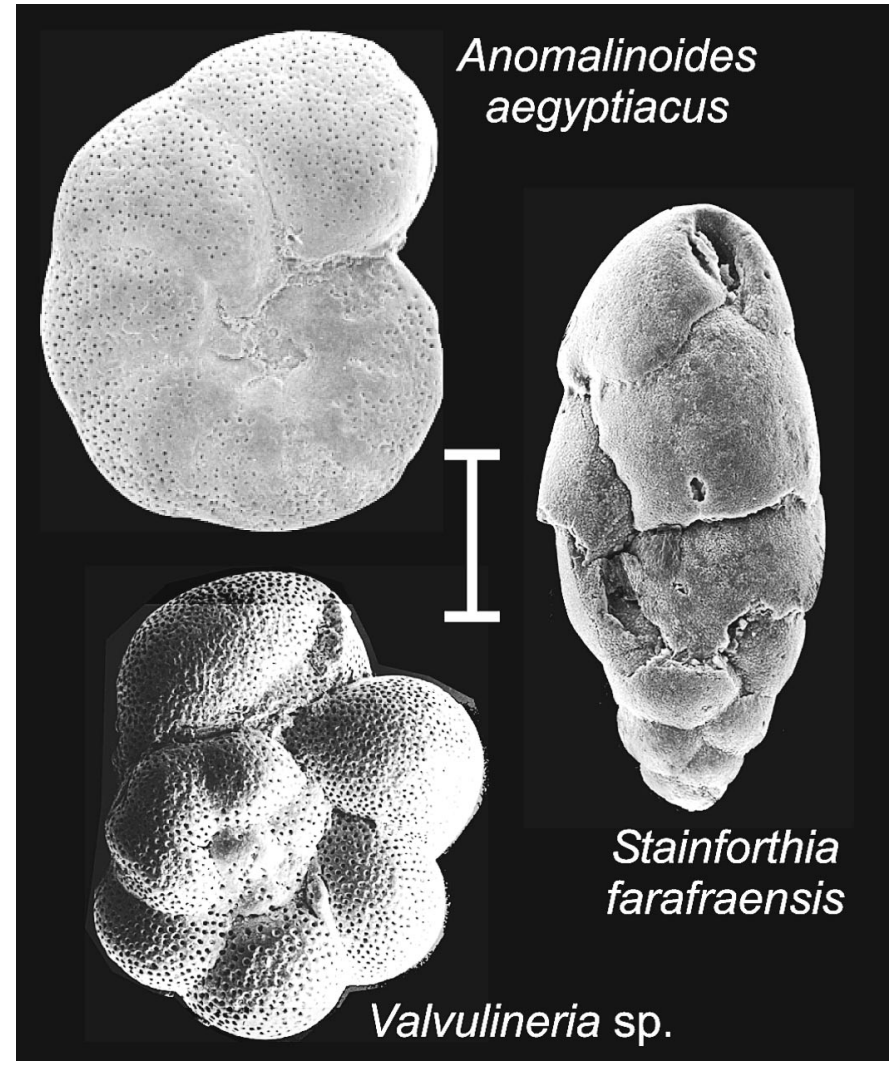

Figure 6. Dominant benthic foraminifera taxa of Anomalinoides aegyptiacus assemblage (Fig. 4), together composing up to $95 \%$ of benthic assemblages in late Paleocene thermal maximum black shales and in equivalent fissile marl at Duwi. Scale bar is $100 \mu \mathrm{m}$.

lization) to good (Qreiya). In addition to foraminifera, fish scales and bones are abundant, whereas ostracodes appeared to be absent. Palynologic residues of the black shales did not yield dinocysts, pollen, or spores (H. Brinkhuis, 1999, personal commun.).
Gebel Duwi. The Duwi section presents a special situation for the late Paleocene thermal maximum interval. Subzone P5b is $20 \mathrm{~cm}$ thick, and consists of fissile pink to gray marls (25\% $\left.\mathrm{CaCO}_{3}\right)$ with a modest TOC enrichment $(0.5 \%)$. Despite its different appearance, the well-preserved foraminiferal residues are nearly identical to those of the black shales, both qualitatively and quantitatively. They also both contain numerous phosphatic peloids and common fish remains. The main micropaleontologic difference is the presence of rare ostracodes.

Other black shales in the region. At various levels in $\mathrm{Pa}-$ leocene successions of the region, dark gray and fissile shales to several meters thick are occasionally intercalated. These have also been referred to as black shales (e.g., Benjamini, 1992), but should not be confused with the late Paleocene thermal maximum black shales. Unlike the latter, these black shales are generally composed of strongly fissile (not laminated) shales with a very low $\mathrm{CaCO}_{3}$ content (e.g., the smectite-rich P2-P3 interval of the Ben Gurion 400 section; Benjamini, 1992; Schmitz et al., 1997; Bolle et al. 2000a). Their foraminifera assemblages either correspond to the background assemblages described here or are poorly preserved and dominated by thickshelled benthic foraminifera and/or agglutinated taxa, indicating postdepositional dissolution (e.g., Speijer and Schmitz, 1998; Speijer's data on Ben Gurion). The fissile black shales $1 \mathrm{~m}$ below the benthic extinction event in the Ben Gurion section contain no planktic foraminifera and larger numbers of buliminid taxa (Benjamini, 1992), and are compositionally, stratigraphically, and genetically unrelated to the late Paleocene thermal maximum black shales discussed here.

Foraminifera-rich calcarenitic marl beds. The calcarenitic marl beds at the base of subzone P5c (Nukhl, Ben Gurion, Aweina, and Duwi) represent the interval with the transition to stable $\delta^{13} \mathrm{C}$ values and thus the upper part of the carbon isotope excursion (Fig. 2). These beds are homogeneous and contain abundant and diverse planktic foraminifera, typically more than 10000 specimens $(>125 \mu \mathrm{m})$ per gram sediment and with 
$\mathrm{P} / \mathrm{B}$ ratios $>95 \%$. Benthic foraminifera and ostracode assemblages are also relatively rich and diverse. This bed signals a gradual transition to depositional conditions resembling those prevailing prior to the late Paleocene thermal maximum.

\section{DISCUSSION}

\section{Thermal maturation or weathering effect of late Paleocene thermal maximum black shales?}

Two mechanisms are envisaged to explain the observed extremely low hydrocarbon yields and high $T_{\max }$ values of the black shales. Such pyrolytic signatures argue for severe influence of weathering effects, or for postdepositional thermal heating of the successions studied. Pyrolytic signatures of various Cretaceous and Neogene sections from the Gulf of Suez area show $T_{\max }$ values in general below $432^{\circ} \mathrm{C}$ and corresponding HI ranging from 300 to $676 \mathrm{mg} \mathrm{HC/g}$ TOC (Mostafa, 1993), which would suggest that material studied in this paper has been subjected to intense weathering. Alternatively, heating of the sediments related to tectonic mechanisms has to be considered in view of the geotectonic position of the studied localities close to the Red Sea rift system (Fig. 1). Following this interpretation we refer to a correlation of rank parameters recently compiled by the Shipboard Scientific Party (1998) of ODP Leg 171B in which $T_{\max }$ values of $\sim 500^{\circ} \mathrm{C}$ would correspond to peak burial temperatures to $180^{\circ} \mathrm{C}$. At such temperatures most oil-prone kerogen has stopped producing liquid hydrocarbons, leaving a residual organic fraction in the original sedimentary beds. The observation of a weak, mostly dark brownish fluorescence in the laminated late Paleocene thermal maximum shales is consistent with that interpretation; however, it does not rule out any influence of weathering processes. Fluorescence intensity decreases and fluorescence color shifts to higher wavelengths (from yellow to brown) with increasing thermal maturity (Tissot and Welte, 1984).

Assuming an average geothermal gradient of $\sim 30^{\circ} \mathrm{C} / \mathrm{km}$, alteration of late Paleocene thermal maximum black shales at peak temperatures of $\sim 180^{\circ} \mathrm{C}$ require a sediment overburden of $\sim 5-6 \mathrm{~km}$. Stratigraphic data, however, indicate that overburden in the Eastern Desert (Nezzi and Qreiya) probably did not exceed $\sim 1 \mathrm{~km}$ (Said, 1990), which would lead to burial temperatures of only $\sim 50^{\circ} \mathrm{C}$. We speculate that rifting of the Red Sea and the Gulf of Suez during the late Cenozoic may have provided sufficient additional heat to the surrounding continental margins, including its Paleogene sedimentary cover, to cause the high peak temperatures of the black shales suggested by the pyrolytic analysis. Considering the realistic Paleocene $\delta^{13} \mathrm{C}$ values (see also Schmitz et al., 1996), this heating apparently did not have a great influence on stable isotopic signatures.

\section{Relative sea-level change across the late Paleocene thermal maximum}

Sedimentologic and micropaleontologic data indicate fluctuations in relative sea level in an interval bracketing the late Paleocene thermal maximum in Egypt (Fig. 4). The microbiota of the neritic sections in particular enable reconstruction of the relative sea-level curve for the area. Sections in the Eastern and Western Deserts indicate maximum transgression coinciding with largest paleodepths during late Paleocene biochrons P4 and NP8 at 57 Ma (Luger, 1985; Speijer and Schmitz, 1998). This is followed by general regression and shallowing into the early Eocene. Two regressive and/or shallowing peaks are superimposed on this overall regressive trend. One large sea-level fluctuation $(\sim 70 \mathrm{~m})$ within biochron P5c close to the NP9NP10 boundary was demonstrated in the Aweina section (Speijer and Schmitz, 1998). A sea-level fluctuation of lesser magnitude, previously unnoticed in Egypt, encompasses the late Paleocene thermal maximum. In the Duwi section, just prior to the late Paleocene thermal maximum, deeper dwelling ostracoda gradually disappear, replaced by shallower taxa and indicating shallowing from $80-100 \mathrm{~m}$ to $50-70 \mathrm{~m}$. At the onset of the late Paleocene thermal maximum this trend rapidly reverses and deeper conditions (70-100 m) were attained again (Speijer and Morsi, 2002). We also find a succession of last appearances of deeper dwelling benthic foraminifera in the Duwi section, also indicative of shallowing immediately prior to the late Paleocene thermal maximum. The subsequent deepening is not clear from the benthic foraminiferal record. With the onset of basin-wide decrease of oxygenation and increase of food levels at the seafloor, the previously established bathymetric gradient in benthic foraminifera assemblages became disrupted. A low-diversity A. aegyptiacus assemblage dominated at all depths studied. As normal conditions returned and benthic foraminifera assemblages again became established along a bathymetric gradient, water depths were similar to those prior to the late Paleocene thermal maximum.

Sedimentologic observations provide additional indications for relative sea-level fluctuations in the studied interval In sections like Aweina and Ben Gurion, the top of the pre-late Paleocene thermal maximum succession is eroded and the early part of the late Paleocene thermal maximum (i.e., the black shale) is lost in a hiatus, indicated by an omission surface. In Nezzi, the black shale fills a channel (P. Luger, 1998, personal commun.). In numerous sections on Sinai, Lüning et al. (1998) also found discontinuities within the NP9-NP10 interval. Our observations on this Sinai material indicate that these discontinuities also include the late Paleocene thermal maximum. These discontinuities are likely the result of changes in the interplay between sediment input, carbonate production, redistribution, and relative sea-level change.

In a sequence stratigraphic interpretation (Fig. 4), using EXXON nomenclature (e.g., Haq et al., 1988), the beds underlying the late Paleocene thermal maximum represent the late 
highstand systems tract and subsequent lowstand systems tract. The black shales with numerous peloids and fish remains suggest slow sedimentation typical of a condensed sequence, representing the early part of the transgressive systems tract. The overlying, often calcarenitic, beds with high numbers of planktic foraminifera seem to result from a continuation of condensed sedimentation (reduction of input from land, but high carbonate production; see following), representing the maximum flooding surface and the transition to the next highstand systems tract. Thus, a complete short-term (third or fourth order) sea-level cycle appears to envelope the late Paleocene thermal maximum. Foraminiferal abundance and $\mathrm{CaCO}_{3}$ data indicate that the next highstand systems tract was reached well before $\delta^{13} \mathrm{C}$ values stabilized. These observations indicate that the transgressive systems tract containing the black shales at its base had a duration similar to that of the late Paleocene thermal maximum ( $\sim 90$ k.y.), using the temporal data of the carbon isotope excursion ( $\sim 220$ k.y.) by Röhl et al. (2000).

\section{Eustatic sea-level rise at the onset of the late Paleocene thermal maximum}

A very similar black shale in the same stratigraphic position has been recorded in numerous sections on the northern margin of the Tethys (Gavrilov et al., 1997; Speijer et al., 1997). It contains phosphatic concentrations and enrichments of a suite of elements typical for deposition under suboxic to anoxic conditions (Gavrilov et al., 1997). Also similar to the Egyptian record, these black shales constitute a condensed deposit during a transgressive pulse. However, this transgressive pulse is superimposed on a long-term transgressive trend (Gavrilov et al., 1997), not on a regressive one as in the Middle East. Apparently, at least one of these long-term trends does not relate to eustatic change, but rather to the general tectonic development of the individual continental margin.

Some of the best-studied neritic records across the late $\mathrm{Pa}$ leocene thermal maximum are found in the subsurface of the New Jersey coastal plain. The investigation of numerous cores shows a complicated stratigraphic architecture of upper Paleocene and lower Eocene rocks, characterized by numerous smaller and larger gaps (Olsson and Wise, 1987, Gibson et al., 2000). The late Paleocene thermal maximum in this area is characterized by the transition from glauconite-rich clayey sands and sandy clays to clays. The two cores currently providing the best record across this interval are the Clayton core (Gibson et al., 1993) and the Bass River core (Cramer et al., 1999). Both studies agree that the lithologic change results from a relative sea-level rise coinciding with the late Paleocene thermal maximum. As in the Tethys, this sea-level rise appears to be associated with the spread of dysoxia on the shelf (Olsson and Wise, 1987; Gibson et al., 1993).

Thus, although there are no indications of a sharp sea-level fall on the Asian and North American passive continental margins, there is ample evidence of sea-level rise and/or transgres- sion associated with the onset of the late Paleocene thermal maximum. Although proving synchronicity of sea-level fluctuations from one basin to another is usually a delicate operation, here the time control is very good and suggests that the sea-level rise observed is eustatic in origin and intimately linked to the climatic changes of the late Paleocene thermal maximum. In the Duwi section, an increase in paleodepth of $\sim 20 \mathrm{~m}$ during the late Paleocene thermal maximum is estimated (Speijer and Morsi, 2002). Theoretically this value is composed of a combination of eustatic change, subsidence, compaction, and sediment input. Average subsidence (without correction for compaction) of the Paleocene section of Duwi is $\sim 15 \mathrm{~m} / \mathrm{m}$.y. ( 150 $\mathrm{m}$ total thickness and assuming no significant change in water depth through the $\sim 10$ m.y. of the Paleocene; Said, 1990). Thus, during the $\sim 90$ k.y. of the late Paleocene thermal maximum, average subsidence led to $\sim 1.5 \mathrm{~m}$ deepening, while $\sim 0.5$ $\mathrm{m}$ of compacted sediment accumulated, leading to a net paleodepth increase of only $\sim 1 \mathrm{~m}$. This value is negligible; assuming no major tectonic reorganization, an $\sim 20$ m eustatic rise can be inferred. There are no estimates for the amount of sea-level rise in the other regions and so this value is currently the best estimate of a possible eustatic change coinciding with the late Paleocene thermal maximum.

This coincidence also makes it plausible that both are causally linked. The current best explanation for the rapidity and magnitude of the carbon isotope excursion is the massive release of methane from deep-sea sediment reservoirs (Dickens et al., 1995; Bains et al., 1999; Katz et al., 1999; Dickens, 2000a). Bains et al. (1999) and Röhl et al. (2000) suggested that there were two or three main phases of methane release within a 20 k.y. period at the onset of the late Paleocene thermal maximum. These would be a response to deep-sea warming and may have acted as a positive feedback for climate warming during the late Paleocene thermal maximum.

An additional consequence of deep-sea warming would be the thermal expansion of the oceanic water column. This expansion would be $\sim 1 \mathrm{~m} /{ }^{\circ} \mathrm{C}$ (Schulz and Schäfer-Neth, 1997) for an expanding water column of $4 \mathrm{~km}$. During the late Paleocene thermal maximum, deep ocean temperatures warmed by 4- $8^{\circ} \mathrm{C}$ (Kennett and Stott, 1991; Zachos et al., 1993). Depending on how much of the entire water column was involved in the deep-sea warming, the resulting sea-level rise would be $\sim 4$ $8 \mathrm{~m}$ at the most. This would account for less than half of the inferred sea-level rise. Additional sea-level rise may have been generated by the melting of polar ice caps and high-altitude ice covers. However, there is little evidence of polar ice during the Paleocene, also because of a general lack of high-latitude Paleocene deposits. The potential global waxing and waning of mountainous glaciers at that time is similarly difficult to quantify. Significant amounts of water stored in soils and lakes may have been transferred to the oceanic reservoir as a response to global warming, but these cannot have been sufficient to account for the rest of the inferred sea-level rise. However, a eustatic rise of $\sim 20 \mathrm{~m}$ within $<100$ k.y. is difficult to explain 
without calling upon glacio-eustatic changes in addition to the thermal expansion of oceanic water. This shows that the sealevel record at late Paleocene thermal maximum time demands a careful examination of other continental margin records.

\section{Formation of the black shales and foraminifera-rich marls}

There are various models for the formation of black shales: a common factor in all of them is a considerable degree of oxygen deficiency at the seafloor (Wignall, 1994). For certain periods of black shale formation (e.g., in the Cretaceous), even fully anoxic conditions on an ocean-wide scale have been suggested (e.g., Arthur et al., 1987; Sinninghe Damsté and Köster, 1998). However, in many black shales, evidence of benthic life is present in the form of benthic microfauna or small burrows, i.e., the quasianaerobic biofacies (Koutsoukos and Hart, 1990; Savrda and Bottjer, 1991; Tyson and Pearson, 1991). Benthic foraminifera are the most common group of shelly benthic microbiota in recent oxygen-deficient environments and in black shales. This group has numerous representatives that appear to thrive under such conditions (e.g., Sen Gupta and MachainCastillo, 1993; Bernhard, 1996). Experimental and field studies indicate that some species are able to survive under fully anoxic conditions (e.g., Moodley and Hess, 1992; Bernhard, 1996; Bernhard et al., 1997). However, it has not been demonstrated that reproduction can take place in the absence of oxygen, and thus long-term anoxia would lead to disappearance of all living benthic foraminifera and stop in situ shell production.

The late Paleocene thermal maximum black shales studied here show a fine wavy-laminated microtexture, indicating a general absence of bioturbating organisms and suboxic to anoxic conditions within the sediment (Wignall, 1994). The wavy character of the lamination results from compaction of the finegrained sediment around the larger grains such as peloids and microfauna (Wignall, 1994). In situ, opportunistic benthic foraminifera are present in very low numbers in all black shales studied, thus representing a quasianaerobic biofacies. Considering that microhabitat preferences are not fixed, but rather show a dynamic response to oxygen and nutrient gradients at the top of the sediment (Jorissen et al., 1995; van der Zwaan et al., 1999), we assume that all common to abundant (in a relative sense) benthic taxa (A. aegyptiacus, Stainforthia farafraensis, and Valvulineria sp.) lived on top of the sediment. Their very low numbers (in an absolute sense) cannot be caused by postmortem destruction; the shells of planktic foraminifera are abundant and both are well preserved, especially in Qreiya (as in the fissile marls of Duwi). These black shale characteristics and inferred ecologic responses suggest that bottom-water conditions may either have been suboxic throughout or may have fluctuated between anoxic and suboxic or dysoxic. In modern environments, stable suboxic conditions tend to favor certain adapted microbiota to proliferate, leading to high-standing stocks and large numbers of tests (Bernhard et al., 1997; van der Zwaan et al., 1999). The late Paleocene thermal maximum black shales, however, yield very low numbers of opportunistic benthic foraminifera, despite the lack of postmortem loss and the somewhat condensed nature of the sediment. Thus, from a numeric perspective we exclude the possibility that the bottom water was permanently suboxic and adopt the alternative that the conditions fluctuated between anoxic and suboxic or dysoxic. We hypothesize that during extended periods of anoxia, all local benthic organisms became extinct. During brief periods of improved ventilation, some pioneer benthic taxa were able to colonize the seafloor from shallower areas, protected from severe anoxia (see Speijer et al., 1997, for details on extinction and repopulation patterns). In order to preserve lamination and to prevent pioneer taxa from producing abundant offspring, ventilation of the seafloor must have been a rare and short-lived event, for example following severe storms.

\section{Productivity changes}

It was suggested earlier that primary production and the vertical organic carbon flux in this basin increased considerably during the latest Paleocene and particularly during deposition of the black shales and calcarenitic marls associated with the late Paleocene thermal maximum and carbon isotope excursion (Speijer, 1994; Schmitz et al., 1997; Speijer et al., 1997; Charisi and Schmitz, 1998; Speijer and Schmitz, 1998). TOC enrichment of the black shales is consistent with this (e.g., Calvert and Pedersen, 1992; Bertrand and Lallier-Vergès, 1993), particularly because the bulk of the TOC is represented by amorphous organic matter of marine origin and the TOC contents are expected to have been considerably higher before thermal maturation. The domination of the benthic foraminifera A. aegyptiacus is thought to be typical for eutrophic conditions (Speijer et al., 1996b).

Biotic evidence for productivity changes of the pelagic ecosystem during the late Paleocene thermal maximum is highly equivocal. The only pelagic organisms in the black shales and overlying foraminifera-rich marls are calcareous nannoplankton and planktic foraminifera. Monechi et al. (2000) noted the blooming of Coccolithus pelagicus during the late Paleocene thermal maximum in Egypt. In the modern ocean, blooms of this taxon typify high-latitude oceans as well as midlatitude upwelling systems (Baumann et al., 2000; Cachao and Moita, 2000). In Mediterranean Quaternary sediments, C. pelagicus shows abundance peaks associated with intervals characterized by sapropels (Müller, 1985). These distribution data strongly suggest that the late Paleocene thermal maximum is characterized by enhanced biological productivity through upwelling.

Among the planktic foraminifera, the genus Acarinina, including the species $A$. africana and $A$. sibaiyaensis, is unusually abundant in the black shales, largely at the expense of Morozovella. Both genera are usually considered as surface dwellers typical for oligotrophic conditions (e.g., Boersma and PremoliSilva, 1991; Hallock et al., 1991; Berggren and Norris, 1997). 
The same dramatic compositional change during the late $\mathrm{Pa}$ leocene thermal maximum was observed in the central Pacific ocean and interpreted as an indication for extreme oligotrophy (Kelly et al., 1996, 1998). However, we consider it very unlikely that conditions resembling extreme oligotrophy of an open ocean could ever have prevailed in this marginal basin. Humid and warm conditions prevailing on the southeastern continent at this time led to enhanced kaolinite input into the basin (Bolle et al., 2000b) and would have supplied sufficient nutrients to prevent the basin from becoming extremely oligotrophic. This paradox demonstrates that the current understanding of the autecology of Paleogene planktic foraminifera is still quite poor.

Radiolaria are often associated with modern and ancient upwelling systems. In the studied region, radiolaria are fairly abundant only in the basal meters of the Esna Formation (and lateral equivalents) in Nukhl and Ben Gurion. Their disappearance prior to the late Paleocene thermal maximum has been used as an argument for a decrease in upwelling strength during the late Paleocene (Benjamini, 1992; Lu et al., 1996). However, benthic foraminifera assemblages from the pre-late Paleocene thermal maximum Esna Formation in Nukhl and Ben Gurion are uniform (Speijer, 1995), regardless of the presence of radiolaria, and suggest oligotrophic deep-water conditions throughout (Speijer et al., 1997). Whatever caused the radiolaria to bloom did not result in an enhanced flux of organic matter to the seafloor, which makes a connection to high productivity less likely. The biogenic barium record of Ben Gurion is also consistent with more or less stable paleoproductivity prior to the late Paleocene thermal maximum (Schmitz et al., 1997).

Diatoms and organic-walled cysts derived from heterotrophic dinoflagellates are other potential indicators for enhanced productivity of surface waters. However, representatives of these groups were not found in the studied sections, neither in background sediments nor in the black shales (H. Brinkhuis and J. Fenner, 1999, personal commun.). Paleocene deposits in Tunisia contain microfaunal assemblages nearly identical to those from Egypt (Speijer et al., 1996b; Kouwenhoven et al., 1997). Because these deposits also provided rich dinocyst assemblages (Bujak and Brinkhuis, 1998; H. Brinkhuis, 2001, personal commun.), we believe that the absence of organic walled dinocysts in the Egyptian sections was probably caused by oxidation or other (postdepositional) effects.

In conclusion, we stress that the TOC enrichment of the black shales was probably not merely caused by enhanced preservation through a decrease in oxygen concentrations of the ambient water, but also resulted from a higher organic carbon flux stimulated by upwelling. This view is in accordance with numerous studies that call upon a combination of higher paleoproductivity and preservation leading to organic-rich deposits (e.g., Calvert and Pedersen, 1992; Bertrand and Lallier-Vergès, 1993). Which primary producers were stimulated remains uncertain. The use of general pelagic proxies (at generic or higher systematic level) for trophic conditions for the late Paleocene is unwarranted and the ecology of the pelagic ecosystem requires a more thorough understanding prior to unequivocally determining changes in biological productivity. From this perspective, it is interesting to note that biogenic barium records suggest increased paleoproductivity during the late Paleocene thermal maximum in several Atlantic and Southern Ocean localities (Bains et al., 2000) and that one of these localities, Ocean Drilling Program Site 1051 (Norris and Röhl, 1999), is marked by the same unusual planktic foraminifera assemblage that typifies the late Paleocene thermal maximum black shale assemblages in Egypt.

\section{Paleoceanographic model}

We envisage the following paleogeographic and paleoceanographic configurations for the studied region during the late Paleocene (Fig. 7). Hemipelagic sedimentation characterized large parts of the epicontinental basin studied. The cosmopolitan character of pelagic and benthic microbiota indicates good surface and bottom connections with the Tethys ocean, despite the presence of Syrian arc swells. These swells may have modulated but not restricted surface- and intermediate-water circulation in and out of the epicontinental basin. The only significant local barrier was the Galala platform in the northern part of the Eastern Desert (Fig. 1; e.g., Kuss et al., 2000). The lack of barriers also means that prevailing surface winds (northeast trade winds) were largely unhindered by geographic obstacles and could lead to upwelling of nutrient-rich deeper waters through offshore Ekman transport (Speijer, 1994; Speijer et al., 1996b). As discussed herein, various micropaleontologic and geochemical proxies indicate upwelling and enhanced biological productivity during the late Paleocene, particularly during and to a lesser extent after the late Paleocene thermal maximum (Schmitz et al., 1996, 1997; Speijer et al., 1996b, 1997; Charisi and Schmitz, 1998; Speijer and Schmitz, 1998). Prior to the late Paleocene thermal maximum at a time of gradually falling sea level, elevated biological productivity led to an oxygen minimum zone confined to the shallowest part of the basin (Fig. 7A). Wind stress and high excess evaporation led to an inflow of well-oxygenated Tethyan intermediate water. Deeper parts of the basin were sufficiently ventilated to enable the settlement of diverse benthic communities. Clay-mineral analysis (Bolle et al., 2000a, 2000b) suggests that terrestrial climate was generally warm and arid in the northern part (southern Israel, Sinai) and alternating dry and wet in the southern part (southern Egypt). These climatic conditions could have favored the creation of restricted loci for dense saline water formation, particularly in the northern part of the studied basin. The existence of such loci, however, remains speculative (see also Schmitz et al., 1996; Charisi and Schmitz, 1998). With the onset of the late Paleocene thermal maximum (Fig. 7B), sea level rapidly rose. The inflowing intermediate water from the Tethys, like Pacific and Atlantic intermediate water masses (e.g., Bralower et al., 

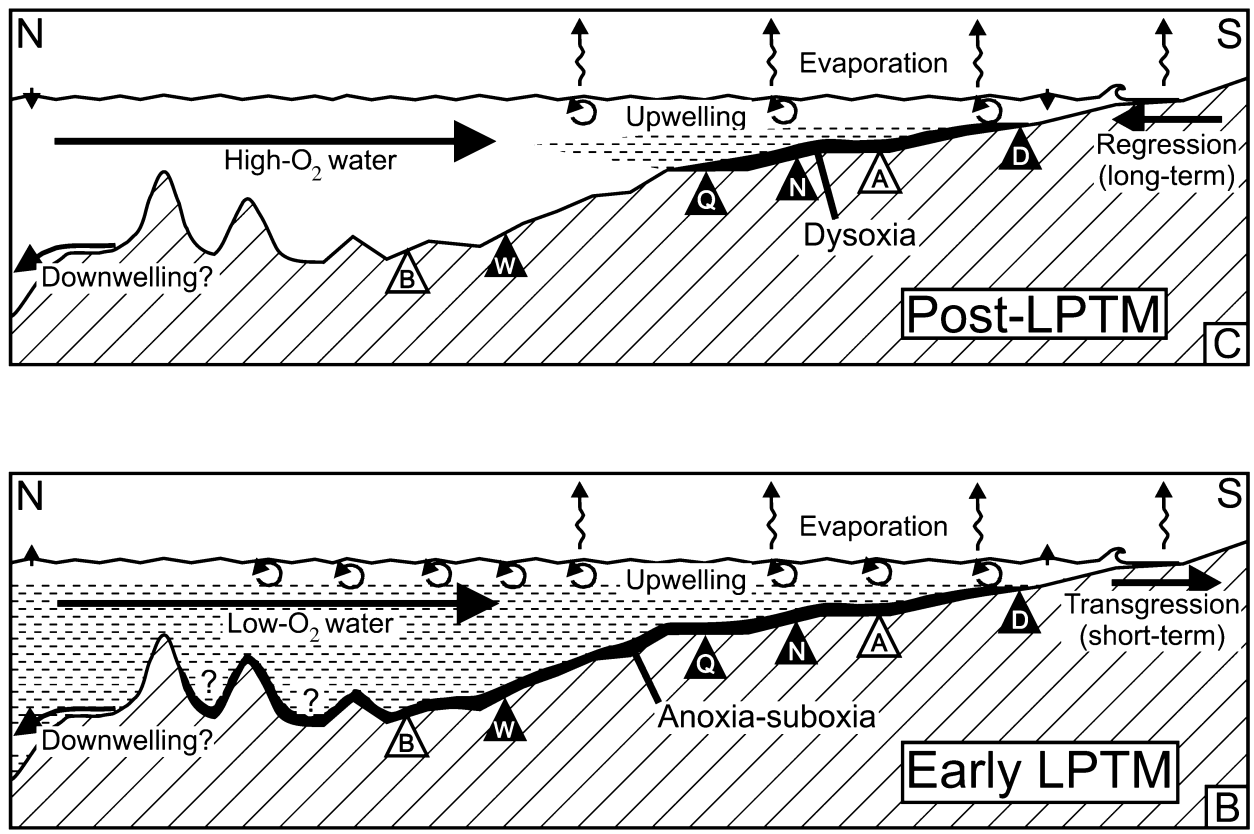

Figure 7. Postulated late Paleocene paleoceanographic conditions in basin covering Eastern Desert, Sinai, and southern Israel. Depth of swells of Syrian arc (unstable shelf) is uncertain. Passages between swells enabled exchange with deep sea Tethys. A: Reconstruction prior to late Paleocene thermal maximum (LPTM). B: Early part of LPTM. C: After LPTM. Triangles are localities studied: B, Ben Gurion; W, Wadi Nukhl; Q, Gebel Qreiya; N, Gebel Nezzi; A, Gebel Aweina; and D, Gebel Duwi.

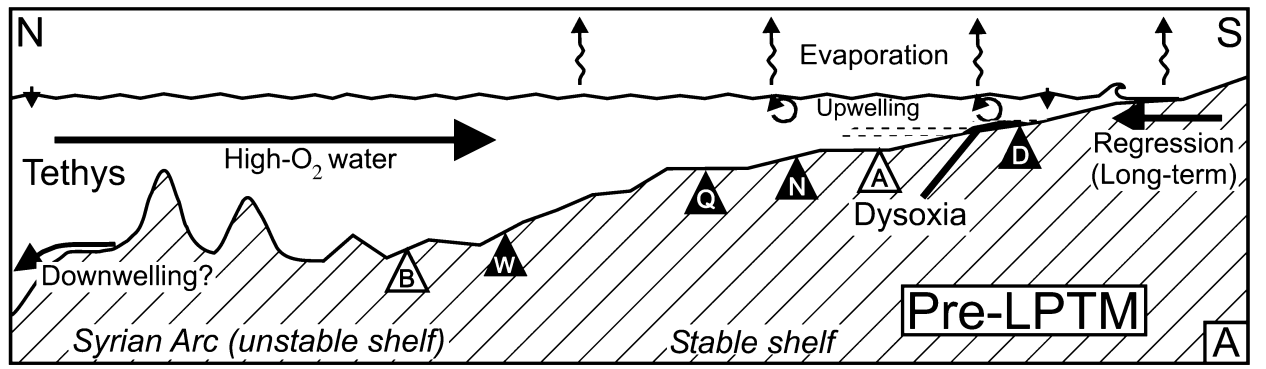

1995; Kaiho et al., 1996; Pardo et al., 1997; Thomas, 1998; Katz et al., 1999; Dickens, 2000a, 2001c), probably contained less dissolved oxygen. Incorporation of this water into epicontinental circulation in combination with intensified upwelling and biological productivity led to severe seafloor anoxia in all studied parts of the basin. Rare ventilation events, e.g., resulting from severe storms, may have occasionally supplied sufficient oxygen for pioneer benthic foraminifera to settle briefly. Increasing humidity on the southeastern landmass brought kaolinite and additional nutrients into the basin (Bolle et al., 2000b). Following the late Paleocene thermal maximum, i.e., from the second half of the carbon isotope excursion onward, elevated productivity associated with a high carbonate production (foraminifera-rich calcarenitic marl beds) persisted through the remainder of the studied interval. At the same time, Tethyan intermediate waters became better oxygenated, so that the oxygen minimum zone (dysoxia at the seafloor) became restricted to neritic environments and bathyal sites were bathed in welloxygenated waters (Fig. 7C). Continental climate was similar to prior to the late Paleocene thermal maximum, although more humid conditions appear to have persisted SE of Duwi (Bolle et al., 2000a, 2000b).

\section{Carbon burial and termination of the carbon isotope excursion}

The magnitude and duration of the carbon isotope excursion are related to several basic components of the global carbon cycle, particularly the mass of carbon in the ocean, and the rates and isotopic compositions of carbon fluxes to and from the ocean (Kump and Arthur, 1999; Dickens, 2001b). Recent studies have highlighted the significance of the carbon isotope excursion, stressing that it can only be explained by a carbon injection to the ocean and atmosphere on a scale similar to that projected for anthropogenic inputs from fossil-fuel combustion (Dickens et al., 1997; Norris and Röhl, 1999; Bains et al., 2000). Although many Paleogene conditions were different from those of today, the late Paleocene thermal maximum may offer an analog for how global biogeochemical cycles responded to a massive input of carbon (Dickens et al., 1997). 
One particularly relevant issue is the rate at which the carbon isotope excursion returns to pre-carbon isotope excursion values, because this represents the removal of excess carbon from the ocean and atmosphere after carbon injection (Dickens, 2001b). Norris and Röhl (1999) estimated that the carbon isotope excursion lasted $\sim 150$ k.y. Assuming a Paleogene carbon cycle with masses and fluxes similar to present, this response is shorter than predicted ( $\sim 200$ k.y.) if inputs from rivers, volcanoes, and weathering and outputs to carbonate and organic matter remained constant after carbon injection. There are several possible explanations for the discrepancy, of which two seem particularly plausible (Dickens, 2001b): (1) the total carbon inputs and outputs were enhanced or (2) the burial of organic matter increased relative to carbonate. The high TOC contents of sediment deposited during the late Paleocene thermal maximum in the northern Tethys (Gavrilov et al., 1997; Speijer et al., 1997) and the southern Tethys are consistent with the second explanation. They may also support the first explanation if the flux of TOC increased. TOC contents increased from $\sim 0.1 \%$ to $\sim 2 \%$ in Egyptian black shales and to $17 \%$ in northern Tethyan black shales (Gavrilov et al., 1997), marking a 20-170 fold increase. Although sedimentation rates decreased at the same time in response to sea-level rise, it is unrealistic to explain the entire TOC increase by condensation, and thus the TOC flux increased significantly. However, at least two basic issues beyond the scope of this paper need to be resolved before carbon removal during the late Paleocene thermal maximum can be defined. First, it is uncertain whether TOC concentrations increased in other marine sediments, deep and shallow; records from other locations do not show strongly enhanced TOC contents across the late Paleocene thermal maximum. Second, Röhl et al. (2000) suggested that the duration of the carbon isotope excursion was closer to $\sim 220$ k.y., which may negate the need for enhanced carbon removal after massive carbon injection.

\section{CONCLUSIONS}

On three continental margins, the late Paleocene thermal maximum is associated with transgression and sea-level rise, suggesting a eustatic control. A possible eustatic rise of $\sim 20$ $\mathrm{m}$ could in part (maximum $8 \mathrm{~m}$ ) have resulted from thermal expansion of the oceanic water column. We speculate that the remaining difference may have been caused by glacio-eustatic mechanisms. As sea-level rose, the oxygen minimum zone in the studied basin expanded and intensified, leading to anoxia at the seafloor. This was caused by a combination of inflow of oxygen-deficient Tethyan water (possibly due to methane oxidation) and higher organic carbon flux to the seafloor. TOCrich late Paleocene thermal maximum sediments are widespread along the Tethyan continental margins, and may have played an important role in drawing down carbon that entered the oceans and atmosphere with the onset of the late Paleocene thermal maximum.

\section{ACKNOWLEDGMENTS}

Financial support was provided through grants from the Deutsche Forschungsgemeinschaft (Sp-612/1) and the Zentrale Kommissionen für Forschungsförderung und wissenschaftlichen Nachwuchs (FNK, Bremen University) to Speijer. We thank Jan Smit and an anonymous reader for insightful and constructive reviews, Gerald Dickens, Henk Brinkhuis, and Ken MacLeod for comments and improvements of parts of the text, and Peter Luger for providing samples and stratigraphic logs of the Qreiya and Nezzi sections.

\section{REFERENCES CITED}

Alsharhan, A.S., and Salah, M.G., 1997, A common source rock for Egyptian and Saudi hydrocarbons in the Red Sea: American Association of Petroleum Geologists Bulletin, v. 81, p. 1640-1659.

Arthur, M.A., Schlanger, S.O., and Jenkyns, H.C., 1987, The CenomanianTuronian oceanic anoxic event. 2. Palaeoceanographic controls on organic-matter production and preservation, in Brooks, J., and Fleet, A.J., eds., Marine petroleum source rocks: Geological Society [London] Special Publication 26, p. 401-420.

Aubry, M.-P., Berggren, W.A., and Lucas, E., 1998, Late Paleocene-early Eocene climatic and biotic events in the marine and terrestrial records: New York, Columbia University Press, 513 p.

Bains, S., Corfield, R.M., and Norris, R.D., 1999, Mechanisms of climate warming at the end of the Paleocene: Science, v. 285, p. 724-727.

Bains, S., Norris, R.D., Corfield, R.M., and Faul, K.L., 2000, Termination of global warmth at the Palaeocene/Eocene boundary through productivity feedback: Nature, v. 407, p. 171-174.

Baumann, K.H., Young, J.R., Cachao, M., and Ziveri, P., 2000, Biometric study of Coccolithus pelagicus and its palaeoenvironmental utility: Journal of Nannoplankton Research, v. 22, p. 82.

Benjamini, C., 1992, The Paleocene-Eocene boundary in Israel: A candidate for the boundary stratotype: Neues Jahrbuch für Geologie und Paläontologie, Abhandlungen, v. 186, p. 49-61.

Berggren, W.A., and Norris, R.D., 1997, Biostratigraphy, phylogeny and systematics of Paleocene trochospiral planktonic foraminifera: Micropaleontology, v. 43, Supplement, 116 p.

Berggren, W.A., Kent, D.V., Swisher, C.C., III, and Aubry, M.-P., 1995, A revised Cenozoic geochronology and chronostratigraphy, in Berggren, W.A., Kent, D.V., Aubry, M.-P., and Hardenbol, J., eds., Geochronology, time scales and global stratigraphic correlation: SEPM (Society for Sedimentary Geology), Special Publication 54, p. 129-212.

Bernhard, J.M., 1996, Microaerophilic and facultative anaerobic benthic foraminifera: A review of experimental and ultrastructural evidence: Revue de Paléobiologie, v. 15, p. 261-275.

Bernhard, J.M., and Bowser, S.S., 1999, Benthic foraminifera of dysoxic sediments: Chloroplast sequestration and functional morphology: EarthScience Reviews, v. 46, p. 149-165.

Bernhard, J.M., Sen Gupta, B.K., and Borne, P.F., 1997, Benthic foraminiferal proxy to estimate dysoxic botom-water oxygen concentrations: Santa Barbara Basin, U.S. Pacific continental margin: Journal of Foraminiferal Research, v. 27, p. 10.

Bertrand, P., and Lallier-Vergès, E., 1993, Past sedimentary organic matter accumulation and degradation controlled by productivity: Nature, v. 364, p. 786-788.

Boersma, A., and Premoli-Silva, I., 1991, Distribution of Paleogene planktonic foraminifera: Analogies with the recent?: Palaeogeography, Palaeoclimatology, Palaeoecology, v. 83, p. 29-48.

Bolle, M.P., Pardo, A., Adatte, T., von Salis, K., and Burns, S., 2000a, Climatic 
evolution on the southeastern margin of the Tethys (Negev, Israel) from the Palaeocene to the early Eocene: Focus on the late Palaeocene thermal maximum: Journal of the Geological Society of London, v. 157, p. 929 941.

Bolle, M.P., Tantawy, A.A., Pardo, A., Adatte, T., Burns, S., and Kassab, A., 2000b, Climatic and environmental changes documented in the upper Paleocene to lower Eocene of Egypt: Eclogae Geologicae Helvetiae, v. 93, p. 33-51.

Bralower, T.J., Zachos, J.C., Thomas, E., Parrow, M., Paull, C.K., Kelly, D.C., Silva, I.P., Sliter, W.V., and Lohmann, K.C., 1995, Late Paleocene to Eocene paleoceanography of the equatorial Pacific Ocean: Stable isotopes recorded at Ocean Drilling Program Site 865, Allison Guyot: Paleoceanography, v. 10, p. 841-865.

Bralower, T.J., Thomas, D.J., Zachos, J.C., Hirschmann, M.M., Röhl, U., Sigurdsson, H., Thomas, E., and Whitney, D.L., 1997, High-resolution records of the late Paleocene thermal maximum and circum-Caribbean volcanism: Is there a causal link?: Geology, v. 25, p. 963-966.

Bujak, J.P., and Brinkhuis, H., 1998, Global warming and dinocyst changes across the Paleocene/Eocene Epoch boundary, in Aubry, M.-P., Lucas, S.G., and Berggren, W.A., eds., Late Paleocene-early Eocene climatic and biotic events in the marine and terrestrial records: New York, Columbia University Press, p. 277-295.

Cachao, M., and Moita, M.T., 2000, Coccolithus pelagicus, a productivity proxy related to moderate fronts off western Iberia: Marine Micropaleontology, v. 39, p. 131-155.

Calvert, S.E., and Pedersen, T.F., 1992, Organic carbon accumulation and preservation in marine sediments: How important is anoxia?, in Whelan, J.K., and Farrington, J.W., eds., Organic matter; productivity, accumulation, and preservation in recent and ancient sediments: New York, Columbia University Press, p. 231-263.

Charisi, S.D., and Schmitz, B., 1995, Stable $\left(\delta^{13} \mathrm{C}, \delta^{18} \mathrm{O}\right)$ and strontium $\left({ }^{87} \mathrm{Sr} /\right.$ ${ }^{86} \mathrm{Sr}$ ) isotopes through the Paleocene at Gebel Aweina, eastern Tethyan region: Palaeogeography, Palaeoclimatology, Palaeoecology, v. 116, p. 103-129.

Charisi, S.D., and Schmitz, B., 1998, Paleocene to early Eocene paleoceanography of the Middle East: The $\delta^{13} \mathrm{C}$ and $\delta^{18} \mathrm{O}$ isotopes from foraminiferal calcite: Paleoceanography, v. 13, p. 106-118.

Cramer, B.S., Aubry, M.P., Miller, K.G., Olsson, R.K., Wright, J.D., and Kent, D.V., 1999, An exceptional chronologic, isotopic, and clay mineralogic record of the latest Paleocene thermal maximum, Bass River, New Jersey, Ocean Drilling Program 174AX: Bulletin de la Société Géologique de France, v. 170, p. 883-897.

Dickens, G.R., 2000, Methane oxidation during the late Palaeocene thermal maximum: Bulletin de la Société Géologique de France, v. 171, p. 37-49.

Dickens, G.R., 2001a, Carbon addition and removal during the Late Palaeocene thermal maximum: Basic theory with a preliminary treatment of the isotope record at Ocean Drilling Program Site 1051, Blake Nose, in Kroon, D., Norris, R., and Klaus, A., eds., Western North Atlantic Palaeogene and Cretaceous palaeoceanography: Geological Society [London] Special Publication 183, p. 293-306.

Dickens, G.R., 2001b, On the fate of past gas: What happens to methane released from a bacterially mediated gas hydrate capacitor?: Geochemistry, Geophysics, Geosystems, v. 2, Paper number 2000GC000131 (Available at http://www.gcubed.org).

Dickens, G.R., O’Neil, J.R., Rea, D.K., and Owen, R.M., 1995, Dissociation of oceanic methane hydrate as a cause of the carbon isotope excursion at the end of the Paleocene: Paleoceanography, v. 10, p. 965-971.

Dickens, G.R., Castillo, M.M., and Walker, J.C.G., 1997, A blast of gas in the latest Paleocene: Simulating first-order effects of massive dissociation of oceanic methane hydrate: Geology, v. 25, p. 259-262.

Espitalié, J., Deroo, G., and Marquis, F., 1985, La pyrolyse Rock-Eval et ses applications: Revue de l'Institut Français du Pétrole, v. 40, p. 25-89.

Gavrilov, Y.O., Kodina, L.A., Lubchenko, I.Y., and Muzylev, N.G., 1997, The late Paleocene anoxic event in epicontinental seas of peri-Tethys and for- mation of the sapropelite unit: Sedimentology and geochemistry: Lithology and Mineral Resources, v. 32, p. 427-450.

Gibson, T.G., Bybell, L.M., and Owens, J.P., 1993, Latest Paleocene lithologic and biotic events in neritic deposits of southwestern New Jersey: Paleoceanography, v. 8, p. 495-514.

Gibson, T.G., Bybell, L.M., and Mason, D.B., 2000, Stratigraphic and climatic implications of clay mineral changes around the Paleocene/Eocene boundary of the northeastern US margin: Sedimentary Geology, v. 134, p. 65-92.

Hallock, P., Premoli-Silva, I., and Boersma, A., 1991, Similarities between planktonic and larger foraminiferal evolutionary trends through Paleogene paleoceanographic changes: Palaeogeography, Palaeoclimatology, Palaeoecology, v. 83, p. 49-64.

Haq, B.U., Hardenbol, J., and Vail, P., 1988, Mesozoic and Cenozoic chronostratigraphy and cycles of sea level change, in Wilgus, C.K., et al., eds., Sea-level changes: An integrated approach: Society of Economic Paleontologists and Mineralogists, Special Publication 42, p. 71-108.

Jones, R.W., 1987, Organic facies: Advances in petroleum geochemistry, v. 2, p. $1-90$.

Jorissen, F.J., de Stigter, H.C., and Widmark, J.G.V., 1995, A conceptual model explaining benthic foraminiferal microhabits: Marine Micropaleontology, v. 26 , p. $3-15$.

Kaiho, K., Arinobu, T., Ishiwatari, R., Morgans, H.E.G., Okada, H., Takeda, N., Tazaki, K., Zhou, G., Kajiwara, Y., Matsumoto, R., Hirai, A., Niitsuma, N., and Wada, H., 1996, Latest Paleocene benthic foraminiferal extinction and environmental changes at Tawanui, New Zealand: Paleoceanography, v. 11, p. 447-465.

Katz, M.E., Pak, D.K., Dickens, G.R., and Miller, K.G., 1999, The source and fate of massive carbon input during the latest Paleocene thermal maximum: Science, v. 286, p. 1531-1533.

Kelly, D.C., Bralower, T.J., Zachos, J.C., Premoli Silva, I., and Thomas, E., 1996, Rapid diversification of planktonic foraminifera in the tropical Pacific (ODP Site 865) during the late Paleocene thermal maximum: Geology, v. 24, p. 423-426.

Kelly, D.C., Bralower, T.J., and Zachos, J.C., 1998, Evolutionary consequences of the latest Paleocene thermal maximum for tropical planktonic foraminifera: Palaeogeography, Palaeoclimatology, Palaeoecology, v. 141, p. $139-161$.

Kennett, J.P., and Stott, L.D., 1991, Abrupt deep-sea warming, palaeoceanographic changes and benthic extinctions at the end of the Palaeocene: Nature, v. 353 , p. $225-229$.

Koch, P.L., Zachos, J.C., and Gingerich, P.D., 1992, Correlation between isotope records in marine and continental carbon reservoirs near the Palaeocene/Eocene boundary: Nature, v. 358, p. 319-322.

Koutsoukos, E.A.M., and Hart, M.B., 1990, Cretaceous foraminiferal morphogroup distribution patterns, palaeocommunities and trophic structures: A case study from the Sergipe Basin, Brazil: Transactions of the Royal Society of Edinburgh: Earth Sciences, v. 81, p. 221-246.

Kouwenhoven, T.J., Speijer, R.P., Van Oosterhout, C.W.M., and Van der Zwaan, G.J., 1997, Benthic foraminiferal assemblages between two major extinction events; the Paleocene El Kef section, Tunisia: Marine Micropaleontology, v. 29, p. 105-127.

Kuhnt, W., Herbin, J.P., Thurow, J., and Wiedmann, J., 1990, Distribution of Cenomanian-Turonian organic facies in the western Mediterranean and along the adjacent Atlantic margin, in Huc, A.Y., ed., Deposition of organic facies, American Association of Petroleum Geologists Studies in Geology, v. 30, p. 133-160

Kump, L.R., and Arthur, M.A., 1999, Interpreting carbon-isotope excursions: Carbonates and organic matter: Chemical Geology, v. 161, p. 181-198.

Kuss, J., Scheibner, C., and Gietl, R., 2000, Carbonate to platform transition along an upper Cretaceous to lower Tertiary Syrian Arc uplift, Galala Plateaus, Eastern Desert of Egypt: GeoArabia, v. 5, p. 405-424.

Lu, G., Keller, G., Adatte, T., and Benjamini, C., 1996, Abrupt change in the upwelling system along the southern margin of the Tethys during the 
Paleocene-Eocene transition event: Israel Journal of Earth Sciences, v. 44, p. 185-195.

Luger, P., 1985, Stratigraphie der marinen Oberkreide und des Alttertiärs im südwestlichen Obernil-Becken (SW-Ägypten) unter besonderer Berücksichtigung der Mikropaläontologie, Palökologie und Paläogeographie: Berliner Geowissenschaftliche Abhandlungen, Reihe A: Geologie und Paläontologie, v. 63, 151 p.

Lüning, S., Marzouk, A.M., and Kuss, J., 1998, The Paleocene of central East Sinai, Egypt: "Sequence stratigraphy" in monotonous hemipelagites: Journal of Foraminiferal Research, v. 28, p. 19-39.

Mart, Y., 1991, Some Cretaceous and early Tertiary structures along the distal continental margin of the southeastern Mediterranean: Israel Journal of Earth Sciences, v. 40, p. 77-90.

Mello, M.R., Telnaes, N., and Maxwell, J.R., 1995, The hydrocarbon source potential in the Brazilian marginal basins: A geochemical and paleoenvironmental assessment, in Huc, A.Y., ed., Paleogeography, paleoclimate, and source rocks: American Association of Petroleum Geologists Studies in Geology 40, p. 233-272.

Monechi, S., Angori, E., and Speijer, R.P., 2000, Upper Paleocene biostratigraphy in the Mediterranean region: Zonal markers, diachronism and preservational problems: GFF, v. 122, p. 108-110.

Moodley, L., and Hess, C., 1992, Tolerance of infaunal benthic for low and high oxygen concentrations: The Biological Bulletin, v. 183, p. 94-98.

Mostafa, A.E.D.R., 1993, Organic geochemistry of source rocks and related crude oils in the Gulf of Suez area, Egypt, 147 of Berliner Geowissenschaftliche Abhandlungen, Reihe A: Berlin, Selbstverlag Fachbereich Geowissenschaften, FU Berlin, 163 p.

Müller, C., 1985, Late Miocene to recent Mediterranean biostratigraphy and paleoenvironments based on calcareous nannoplankton, in Stanley, D.J., and Wezel, F.C., eds., Geological evolution of the Mediterranean Basin: New York, Springer-Verlag, p. 471-485.

Norris, R.D., and Röhl, U., 1999, Carbon cycling and chronology of climate warming during the Palaeocene/Eocene transition: Nature, v. 401, p. 775778.

Olsson, R.K., and Wise, S.W., Jr., 1987, Upper Paleocene to middle Eocene depositional sequences and hiatuses in the New Jersey Atlantic Margin, in Ross, C.A., and Haman, D., eds., Timing and depositional history of eustatic sequences: Constraints on seismic stratigraphy: Cushman Foundation for Foraminiferal Research, Special Publication 24, p. 99-112.

Pardo, A., Keller, G., Molina, E., and Canudo, J.I., 1997, Planktic foraminiferal turnover across the Paleocene-Eocene transition at DSDP Site 401, Bay of Biscay, North Atlantic: Marine Micropaleontology, v. 29, p. 129-158.

Röhl, U., Bralower, T.J., Norris, R.D., and Wefer, G., 2000, New chronology for the late Paleocene thermal maximum and its environmental implications: Geology, v. 28, p. 927-930.

Said, R., 1962, The geology of Egypt: Amsterdam, Elsevier, 377 p.

Said, R., 1990, Cenozoic, in Said, R., ed., The geology of Egypt: Rotterdam, Balkema, p. 451-486.

Savrda, C.E., and Bottjer, D.J., 1991, Oxygen-related biofacies in marine strata: An overview and update, in Tyson, R.V., and Pearson, T.H., eds., Modern and ancient continental shelf anoxia: Geological Society [London] Special Publication 58, p. 201-219.

Schmitz, B., Speijer, R.P., and Aubry, M.-P., 1996, Latest Paleocene benthic extinction event on the southern Tethyan shelf (Egypt): Foraminiferal stable isotopic $\left(\delta^{13} \mathrm{C}, \delta^{18} \mathrm{O}\right)$ records: Geology, v. 24, p. 347-350.

Schmitz, B., Charisi, S.D., Thompson, E.I., and Speijer, R.P., 1997, Barium, $\mathrm{SiO}_{2}$ (excess), and $\mathrm{P}_{2} \mathrm{O}_{5}$ as proxies of biological productivity in the Middle East during the Palaeocene and the latest Palaeocene benthic extinction event: Terra Nova, v. 9, p. 95-99.

Schulz, M., and Schäfer-Neth, C., 1997, Translating Milankovitch climate forcing into eustatic fluctuations via thermal deep water expansion: A conceptual link: Terra Nova, v. 9, p. 228-231.

Sen Gupta, B.K., and Machain-Castillo, M.L., 1993, Benthic foraminifera in oxygen-poor habitats: Marine Micropaleontology, v. 20, p. 183-201.
Shahar, J., 1994, The Syrian arc system: An overview: Palaeogeography, Palaeoclimatology, Palaeoecology, v. 112, p. 125-142.

Shipboard Scientific Party, 1998, Explanatory notes, in Kroon, D., Norris, R.D., et al., eds., Proceedings of the Ocean Drilling Program, Part A, Initial Reports, Leg 171B: College Station, Texas, Ocean Drilling Program, p. $11-44$.

Sinninghe Damsté, J.S., and Köster, J., 1998, A euxinic southern North Atlantic Ocean during the Cenomanian/Turonian oceanic anoxic event: Earth and Planetary Science Letters, v. 158, p. 165-173.

Speijer, R.P., 1994, Extinction and recovery patterns in benthic foraminiferal paleocommunities across the Cretaceous/Paleogene and Paleocene/Eocene boundaries [Ph.D. thesis]: Geologica Ultraiectina, v. 124, 191 p.

Speijer, R.P., 1995, The late Paleocene benthic foraminiferal extinction as observed in the Middle East: Bulletin de la Société Belge de Géologie, v. 103, p. 267-280.

Speijer, R.P., and Morsi, A.M., 2002, Ostracode turnover and sea-level changes associated with the Paleocene-Eocene thermal maximum: Geology, v. 30, p. 23-26.

Speijer, R.P., and Schmitz, B., 1998, A benthic foraminiferal record of Paleocene sea level and trophic/redox conditions at Gebel Aweina, Egypt: Palaeogeography, Palaeoclimatology, Palaeoecology, v. 137, p. 79-101.

Speijer, R.P., Schmitz, B., Aubry, M.-P., and Charisi, S.D., 1996a, The latest Paleocene benthic extinction event: Punctuated turnover in outer neritic foraminiferal faunas from Gebel Aweina, Egypt: Israel Journal of Earth Sciences, v. 44, p. 207-222.

Speijer, R.P., Van der Zwaan, G.J., and Schmitz, B., 1996b, The impact of Paleocene/Eocene boundary events on middle neritic benthic foraminiferal assemblages from Egypt: Marine Micropaleontology, v. 28, p. 99132.

Speijer, R.P., Schmitz, B., and Van der Zwaan, G.J., 1997, Benthic foraminiferal extinction and repopulation in response to latest Paleocene Tethyan anoxia: Geology, v. 25, p. 683-686.

Speijer, R.P., Schmitz, B., and Luger, P., 2000, Stratigraphy of late Palaeocene events in the Middle East: Implications for low- to middle-latitude successions and correlations: Journal of the Geological Society of London, v. 157, p. $37-47$.

Strouhal, A., 1993, Tongeologische Entwicklungstrends in kretazischen und tertiären Sedimenten Nordostafrikas: Regionale Fallbeispiele: Berliner Geowissenschaftliche Abhandlungen, Reihe A: Geologie und Paläontologie, v. 155,68 p.

Thomas, E., 1989, Development of Cenozoic deep-sea benthic foraminiferal faunas in Antarctic waters, in Crame, J.A., ed., Origins and evolution of the Antarctic biota: Geological Society [London] Special Publication 47, p. 283-296.

Thomas, E., 1998, Biogeography of the late Paleocene benthic foraminiferal extinction, in Aubry, M.P., Lucas, S.G., and Berggren, W.A., eds., Late Paleocene-early Eocene climatic and biotic events in the marine and terrestrial records: New York, Columbia University Press, p. 214-243.

Tissot, B.P., and Welte, D.H., 1984, Petroleum formation and occurrence (second edition): Berlin, Springer-Verlag, 699 p.

Tyson, R.V., and Pearson, T.H., 1991, Modern and ancient continental shelf anoxia: An overview, in Tyson, R.V., and Pearson, T.H., eds., Modern and ancient continental shelf anoxia: Geological Society [London] Special Publication 58, p. 1-24.

Tyson, R.V. 1987, The genesis and palynofacies characteristics of marine petroleum source rocks, in Brooks, J., and Fleet, A.J., eds., Marine petroleum source rocks: Geological Society [London] Special Publication 26, p. 47-67.

van der Zwaan, G.J., Duijnstee, I.A.P., den Dulk, M., Ernst, S.R., Jannink, N.T., and Kouwenhoven, T.J., 1999, Benthic foraminifers: Proxies or problems? A review of paleocological concepts: Earth-Science Reviews, v. 46, p. 213-236.

Van Morkhoven, F.P.C.M., Berggren, W.A., and Edwards, A.S., 1986, Cenozoic cosmopolitan deep-water benthic foraminifera: Pau, Elf Aquitaine, Bul- 
letin des Centres de Recherches Exploration-Production Elf-Aquitaine, Memoir 11, $421 \mathrm{p}$.

van Os, B., Middelburg, J.J., and de Lange, G.J., 1996, Extensive degradation and fractionation of organic matter during subsurface weathering: Aquatic Geochemistry, v. 1, p. 303-312.

Wagner, T., and Dupont, L.M., 1999, Terrestrial organic matter in marine sediments: Analytical approaches and eolian-marine records from the central equatorial Atlantic, in Fischer, G., and Wefer, G., eds., The use of proxies in paleoceanography: Examples from the South Atlantic: Heidelberg, Springer-Verlag, p. 547-574.

Wagner, T., and Pletsch, T., 1999, Tectono-sedimentary controls on Cretaceous black shale deposition along the opening equatorial Atlantic gateway (ODP Leg 159), in Cameron, N.R., Bate, R.H., and Clure, V.S., eds., The oil and gas habitats of the South Atlantic: Geological Society [London] Special Publication 153, p. 241-265.

Wignall, P.B., 1994, Black shales: Oxford, Oxford University Press, Oxford Monographs on Geology and Geophysics 30, $127 \mathrm{p}$.

Zachos, J.C., Lohmann, K.C., Walker, J.C.G., and Wise, S.W., 1993, Abrupt climate changes and transient climates during the Paleogene: A marine perspective: Journal of Geology, v. 101, p. 191-213.

MAnuscript Submitted October 17, 2000; AcCePted by the Society MARCH 22, 2001 